\title{
Molecular Mechanisms behind Inherited Neurodegeneration of the Optic Nerve
}

\author{
Alessandra Maresca ${ }^{1, *}$ and Valerio Carelli ${ }^{1,2}$ \\ 1 IRCCS Istituto delle Scienze Neurologiche di Bologna, Programma di Neurogenetica, 40139 Bologna, Italy; \\ valerio.carelli@unibo.it \\ 2 Department of Biomedical and Neuromotor Sciences, University of Bologna, 40139 Bologna, Italy \\ * Correspondence: alessandra.maresca@isnb.it
}

Citation: Maresca, A.; Carelli, V. Molecular Mechanisms behind Inherited Neurodegeneration of the Optic Nerve. Biomolecules 2021, 11, 496. https://doi.org/10.3390/ biom 11040496

Academic Editor: Marta Giacomello

Received: 1 March 2021

Accepted: 23 March 2021

Published: 25 March 2021

Publisher's Note: MDPI stays neutral with regard to jurisdictional claims in published maps and institutional affiliations.

Copyright: (c) 2021 by the authors. Licensee MDPI, Basel, Switzerland. This article is an open access article distributed under the terms and conditions of the Creative Commons Attribution (CC BY) license (https:/ / creativecommons.org/licenses/by/ $4.0 /)$.

\begin{abstract}
Inherited neurodegeneration of the optic nerve is a paradigm in neurology, as many forms of isolated or syndromic optic atrophy are encountered in clinical practice. The retinal ganglion cells originate the axons that form the optic nerve. They are particularly vulnerable to mitochondrial dysfunction, as they present a peculiar cellular architecture, with axons that are not myelinated for a long intra-retinal segment, thus, very energy dependent. The genetic landscape of causative mutations and genes greatly enlarged in the last decade, pointing to common pathways. These mostly imply mitochondrial dysfunction, which leads to a similar outcome in terms of neurodegeneration. We here critically review these pathways, which include (1) complex I-related oxidative phosphorylation (OXPHOS) dysfunction, (2) mitochondrial dynamics, and (3) endoplasmic reticulum-mitochondrial inter-organellar crosstalk. These major pathogenic mechanisms are in turn interconnected and represent the target for therapeutic strategies. Thus, their deep understanding is the basis to set and test new effective therapies, an urgent unmet need for these patients. New tools are now available to capture all interlinked mechanistic intricacies for the pathogenesis of optic nerve neurodegeneration, casting hope for innovative therapies to be rapidly transferred into the clinic and effectively cure inherited optic neuropathies.
\end{abstract}

Keywords: optic atrophy; retinal ganglion cells; complex I; mitochondrial fusion; mitochondrial fission; mitochondria-associated membranes; calcium handling; phospholipids; mitochondrial DNA

\section{Introduction}

Optic atrophy may be an isolated manifestation of a mono-symptomatic disorder, but may also be a quite common feature of complex syndromes characterized by degeneration of multiple neuronal networks [1,2]. The axons forming the optic nerve originate from retinal ganglion cells (RGCs) (Figure 1), the terminal neurons sending the information elaborated by the retina to the brain cortex, through the intermediate stop, along the visual pathway, in the nucleus geniculatus lateralis (LGN) [3]. In addition to optic nerve damage secondary to compressive/infiltrative, inflammatory/autoimmune, or traumatic causes, the vast majority of optic nerve diseases are inherited traits, and within the inherited forms the vast majority is due to mitochondrial dysfunction $[3,4]$.

Mitochondrial diseases are the most common genetic rare disorders, even if individual syndromes may be exremely rare [5-7]. Inheritance follows any of the Mendelian traits, dominant, recessive or X-linked, as over 1000 genes of the nuclear genome (nDNA) encode mitochondrial proteins, precisely 1136 according to the last version of MitoCarta 3.0 [8], including a few in the X-chromosome. Amongst the many forms, Dominant Optic Atrophy Kjer's type (DOA) is the most frequent, and over $70 \%$ of cases can be ascribed to various types of mutations affecting the Optic Atrophy 1 (OPA1) gene, encoding a key protein of the mitochondrial dynamics machinery $[3,4,9]$. However, of great interest is also the multicopy circular mitochondrial DNA (mtDNA), which is exclusively maternally inherited, and follows its own genetic rules resembling those of population genetics $[5-7,10]$. The most 
frequent disease due to mtDNA missense mutations affecting complex I, and leading to oxidative phosphorylation (OXPHOS) deficiency, is Leber's hereditary optic neuropathy (LHON) $[3,4,10]$. As DOA and LHON are largely mono-symptomatic disorders, it must be remarked that an incredibly wide spectrum of other mitochondrial disorders including optic atrophy as defining feature, starting from the DOA "plus" [2,11] and LHON "plus" [2-4] variants, are described and continue to be described. The last in time is the spectrum associated with dominant and recessive mutations affecting the mitochondrial single stranded binding protein (SSBP1) [12-14]. Thus, within the frame of mitochondrial functions, a crossroad of many metabolic pathways, we have at least two major pathogenic mechanisms, possibly interconnected, which may lead to RGCs and their axons' neurodegeneration: complex I-related OXPHOS dysfunction and mitochondrial dynamics $[1-4,15,16]$.

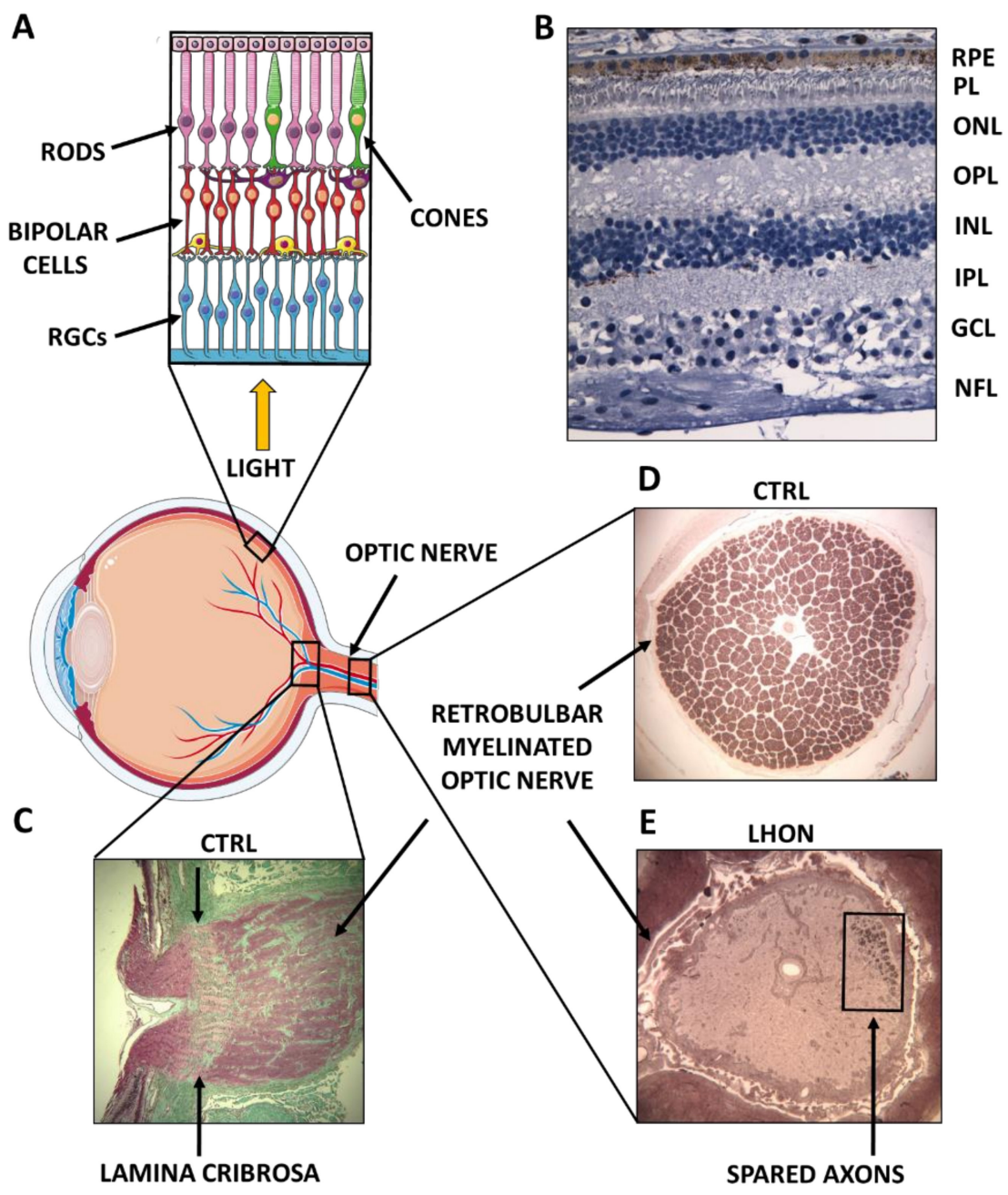

Figure 1. Anatomy of the human retina and optic nerve. (A) Graphical illustration of the eye, with the retina and the optic nerve highlighted. The three key retinal cell types implicated in the visual processing are indicated: photoreceptors (rods and cones), bipolar cells, and ganglion cells (RGCs). The pigment epithelium juxtaposed to photoreceptors, horizontal (purple) and amacrine (yellow) cells are also shown. (B) Histological cross-section of a normal human retina. The layers constituting the retinal tissue are indicated: retinal pigment epithelium (RPE), photoreceptors layer (PL), outer nuclear layer (ONL), outer plexiform layer (OPL), inner nuclear layer (INL), inner plexiform layer (IPL), ganglion cell layer (GCL), and nerve fiber layer (NFL). (C) Histological sagittal section of a normal optic nerve head (post-mortem). The lamina cribrosa, where unmyelinated axonal bundles are organized, is indicated, as well as the post-laminar retrobulbar myelinated optic nerve. (D) Histological cross-section of a normal optic nerve (post-mortem) is shown with myelinated bundles 
hosting about 1.2 million axons. (E) Histological cross-section of an optic nerve (post-mortem) from a patient severely affected by Leber Hereditary Optic Neuropathy (LHON), showing only a few spared axons. Images are a courtesy of Alfredo A. Sadun and Fred N. Ross-Cisneros from Doheny Eye Institute, UCLA, California, USA.

The most relevant forms of isolated or syndromic optic atrophy that apparently do not fit directly the mitochondrial paradigm are those related to Wolframin, with either dominant or recessive mutations, the latter typically causing Wolfram syndrome [17]. This protein is now established to be involved with the contact points between mitochondria and endoplasmic reticulum (ER) [18,19], currently defined as mitochondria-associated ER membranes or MAMs [20]. This qualifies a third major mechanistic area for optic nerve neurodegeneration, involving the complex inter-organellar crosstalk, which, in turn, affects mitochondrial dynamics, in particular fission [21], but also quality control, specifically autophagy [22], ultimately impacting cell survival or death [20].

It must be remarked that none of these mechanistic pathways for optic nerve neurodegeneration is isolated from each other, having plenty of interconnected links, ultimately leading to a few key outcomes, such as impaired axonal transport, dendritic maintenance, myelination turnover, and neuronal cells fate [23].

In this review, we explore the three major areas outlined, as well as some newer emerging mechanisms, connecting the underlying genetic causes with the currently known mechanistic insights relevant for optic nerve neurodegeneration.

\section{Complex I Dysfunction: The Paradigm of Leber's Hereditary Optic Neuropathy (LHON)}

LHON is the paradigm for non-syndromic optic neuropathy, and has a number of peculiar features that make it remarkable. In addition to being maternally inherited, as due to usually homoplasmic mtDNA mutations affecting complex I subunits (m.3460G > $\mathrm{A} / \mathrm{MT}$-ND1, m.11778G > A/MT-ND4, and m.14484T > C/MT-ND6) (Table 1), LHON is characterized by (1) male prevalence, (2) incomplete penetrance in both genders, (3) very cell-specific target, the RGCs, and, finally, (4) a subacute onset and rapidly evolving natural history, which is an unusual feature for neurodegeneration. In a limited subset of cases, we are now aware that an LHON-like disease may occur as a recessive trait, yet involving complex I components encoded by nDNA [24,25].

Table 1. Main genes associated with Complex I dysfunction leading to optic atrophy.

\begin{tabular}{|c|c|c|c|c|}
\hline Gene & Genome & Disease & Inheritance & $\begin{array}{l}\text { Protein } \\
\text { Function }\end{array}$ \\
\hline MT-ND1 & mitochondrial & LHON & MI & CI subunit \\
\hline MT-ND4 & mitochondrial & LHON & MI & CI subunit \\
\hline MT-ND6 & mitochondrial & LHON & MI & CI subunit \\
\hline DNAJC 30 & nuclear & LHON & AR & CI turnover \\
\hline TMEM126A & nuclear & $\begin{array}{l}\text { OA and auditory } \\
\text { neuropathy }\end{array}$ & AR & CI assembly \\
\hline RTN4IP1 & nuclear & $\begin{array}{l}\text { OA with or without } \\
\text { ataxia, ID, and epilepsy }\end{array}$ & AR & CI assembly \\
\hline
\end{tabular}

LHON, Leber Hereditary Optic Neuropathy; MI, maternal inheritance; CI, complex I; AR, autosomal recessive; OA, optic atrophy, ID, intellectual disability.

Thus, complex I dysfunction seems to be one primary mechanism leading to RGCs' neurodegeneration, as at least three downstream consequences are always implicated: (1) only a partially inefficient bioenergetics, as there are multiple alternative pathways to keep mitochondrial respiration ongoing downstream complex I; (2) an increased production of reactive oxygen species (ROS), which, however, remains mostly indirectly documented; and (3) an increased propensity to apoptosis, not necessarily through the canonical pathways implying cytochrome $c$-mediated caspase activation. 
Complex I, the largest of the respiratory complexes composed by about 47 subunits, catalyzes the transfer of two electrons from NADH to ubiquinone, coupled to the translocation of four protons across the inner mitochondrial membrane, to generate the protonmotive force used to ultimately synthesize ATP [26]. As far it concerns the three common mtDNA mutations associated with LHON, now that the complex I structure is much better elucidated [27], there are different types of dysfunction that may be envisaged [3]. Since the early investigations on the biochemical defect induced by LHON mutations, it was clear that only the m.3460G > A/MT-ND1 mutation significantly reduces the enzymatic activity of complex I, as traditionally assessed by a spectrophotometer, providing donor (NADH) and acceptor (ubiquinone) substrates to run the redox reaction [28,29]. The ND1 subunit is now well defined for its role as major component of the pocket hosting the ubiquinone acceptor site [30], thus fully justifying an impaired electron flow and transfer to ubiquinone through the intermediate state of semi-quinone in the presence of the m.3460G $>\mathrm{A} /$ MT-ND1 mutation [27]. In contrast, neither for the most frequent and severe m.11778G $>\mathrm{A} /$ MT-ND4 mutation, nor for the milder m.14484T > C/MT-ND6 mutation, there was a clearly documented reduction of complex I redox activity $[28,29,31-34]$. This finding puzzled for a while the investigators on the pathogenicity of these mutations in LHON [35]. However, complex I-driven synthesis of ATP was clearly impaired with all three LHON primary mutations, certifying their pathogenic role [36]. Interestingly, the early observation on the m.11778G > A/MT-ND4 and m.3460G > A/MT-ND1 mutations documenting the change in rotenone sensitivity in LHON patients $[29,32]$ is now substantiated by the identification of binding sites to this potent complex I inhibitor in both the ND4 and ND1 subunits [37]. This confirms a structural impact of LHON mutations on complex I, possibly reflected in the coupling mechanism [37]. Based on the new understanding of the complex I structure and function, we confirm that the m.3460G > A/MT-ND1 mutation primarily impairs electron transfer to ubiquinone, whereas we may envisage that the $\mathrm{m} .11778 \mathrm{G}>$ A/MT-ND4 and m.14484T > C/MT-ND6 mutations possibly affect proton pumping or coupling of electron transfer with proton pumping $[26,27,37]$. The overall understanding holds true that a combination of bioenergetics impairment and increased ROS production, still needing detailed characterization, leads to increased propensity of cells to undergo apoptosis [38-40].

In addition, LHON has two features that remain peculiar, the gender prevalence, as males are much more prone to undergo the disease than females, and the incomplete penetrance, as many of the mutation carriers remain lifelong unaffected $[1,2,41]$. Both features imply that complex I function may be compensated spontaneously to the point that the disease does not occur. Similarly, complex I function might also be modulated by external factors such as environmental exposures, which may trigger the catastrophic onset of optic nerve degeneration. The mtDNA background, as defined by the genetic variability of haplogroups, has been consistently implicated in LHON penetrance, in particular for the two mutations not affecting complex I redox activity, m.11778G > A/MT-ND4 and m.14484T > C/MT-ND6 mutations [42,43]. Haplogroup J, in fact, has been unequivocally associated with these two mutations [44], implying that the clustering of missense variants affecting complex I and III subunit genes in this mtDNA background may affect the overall complex I and super-complex I + III stability [45]. Interestingly, haplogroup J has also been implicated as the most sensitive to the interaction with environmental toxicants [46] that have been associated with LHON [47], including rotenone [48]. As far it concerns gender, studies based on the cybrid cell model clearly indicated that estrogens ameliorate the metabolic impairment due to LHON mutations by activating mitochondrial biogenesis, providing some insights on female protection [49]. This observation prompted the further substantiation that mitochondrial biogenesis is a compensatory strategy activated by LHON mutations in both genders, possibly by ROS signaling. Thus, the efficiency in activating mitochondrial biogenesis drives LHON penetrance, as individuals remaining unaffected are, on average, much more compensating [50]. A further byproduct of this mechanism is the well-established role played by environmental factors as disease triggers, in particular 
tobacco smoking [51,52], which was shown to hamper the compensatory activation of mitochondrial biogenesis in vivo and in vitro [53].

The recent identification of recessive LHON, involving mutations in the Dna J Homolog Subfamily C Member 30 (DNAJC30) gene, opened a further scenario, which needs better understanding on how might be linked to the "canonical" mtDNA-related LHON [25]. In particular, this recent discovery revealed, by tracking protein turnover in patient-derived cells and a DNAJC30-knockout cell model, a reduced turnover of specific complex I Nmodule subunits, which results into complex I impairment. Thus, DNAJC30 operates as a chaperone protein needed for the efficient replacement of complex I subunits exposed to ROS and integral to a mitochondrial complex I repair mechanism [25]. Remarkably, DNAJC30 recessive mutations express phenotypically as LHON, most probably converging on a pathological mechanism common to that of the mtDNA mutations. How this pathological mechanism translates into a catastrophic propagation of RGCs death and axonal degeneration is the next question. The current hypothesis is that the biochemical impairment of complex I reflects on key factors implicated in the peculiar neuronal architecture of RGCs. In fact, these neurons are notorious for having a long stretch of their axons unmyelinated and very energy-dependent, but also related to myelin maintenance, mitochondrial dynamics and transport along the axons, and the vascular co-participation in retinal and axonal physiology [23].

Complex I impairment emerges as a converging theme for optic nerve atrophy also from rarer forms of inherited optic neuropathies, involving genes for which the function is still incompletely elucidated. In particular, the rare recessive form of optic neuropathy associated with mutations in the Transmembrane Protein 126A (TMEM126A) gene (OPA7), sometimes leading to additional neurological features (auditory neuropathy, sensorimotor axonal neuropathy, mild hypertrophic cardiomyopathy), was documented to lead to partial deficiency of complex I in one patient [54]. Concordantly, two recent studies identified TMEM126A as a factor necessary for the correct complex I assembly [55,56]. Furthermore, another recessive form of isolated or syndromic optic neuropathy associated with mutations in the Reticulon 4 Interacting Protein 1 (RTN4IP1) gene (OPA10) has been reported to present with a combined defect of complex I and IV [57], but also with a profound complex I defect when associated with the severe phenotype [58]. Interestingly, the RTN4IP1 gene encodes a mitochondrial protein associated with the outer mitochondrial membrane predicted to interact with the partner Reticulon 4 (RTN4) localized to the ER, implicating the MAM, a further mechanism that is discussed separately.

\section{Mitochondrial Dynamics Failure: From Dominant Optic Atrophy (DOA) to Complex Syndromes}

Mitochondrial "dynamics" refers to alternative cycles of fusion, in which mitochondria merge to renew their composition and stimulate OXPHOS, and fission, in which mitochondria divide into distinct organelles, allowing mtDNA segregation or elimination of damaged/old mitochondria through a selective form of autophagy (mitophagy). In addition to their physiological role, these processes also occur in response to stress conditions or during cell death [59].

Here, we describe the basic mechanisms of mitochondrial dynamics in mammalian cells and consider the pathogenic mechanisms leading to optic atrophy due to mutations in genes encoding for the protein machinery involved in mitochondrial fusion and fission (Table 2). 
Table 2. Main nuclear genes associated with mitochondrial dynamics dysfunction leading to optic atrophy.

\begin{tabular}{|c|c|c|c|c|}
\hline Gene & $\begin{array}{l}\text { Effect on Mitochondrial } \\
\text { Network }\end{array}$ & Disease & Inheritance & Protein Function \\
\hline OPA1 & Fragmented & $\begin{array}{c}\text { DOA } \\
\text { DOA-plus }\end{array}$ & $\mathrm{AD}$ & IMM fusion \\
\hline$Y M E 1 L$ & Fragmented & $\begin{array}{c}\text { Mitochondrial encephalopathy with } \\
\text { OA }\end{array}$ & $\mathrm{AR}$ & OPA1 processing \\
\hline AFG3L2 & Fragmented & $\begin{array}{l}\text { DOA with or without additional } \\
\text { neurological features, } \mathrm{CPEO}\end{array}$ & $\mathrm{AD}$ & OMA1 regulation \\
\hline SPG7 & Normal or hyperfused & $\begin{array}{c}\text { DOA } \\
\text { Spastic paraparesis and OA, CPEO }\end{array}$ & $\begin{array}{l}\mathrm{AD} \\
\mathrm{AR}\end{array}$ & OMA1 regulation \\
\hline MFN2 & Fragmented or hyperfused & $\begin{array}{l}\text { CMT with or without OA } \\
\text { HMSN } \\
\text { Lipomatosis and neuropathy }\end{array}$ & $\begin{array}{l}\mathrm{AD} / \mathrm{AR} \\
\mathrm{AD} \\
\mathrm{AR}\end{array}$ & $\begin{array}{l}\text { OMM fusion; MAMs } \\
\text { formation; PS transfer }\end{array}$ \\
\hline$D R P 1$ & Hyperfused & $\begin{array}{c}\text { Mitochondrial encephalopathy with } \\
\text { OA } \\
\text { DOA }\end{array}$ & $\begin{array}{l}\mathrm{AD} / \mathrm{AR} \\
\mathrm{AD}\end{array}$ & OMM fission \\
\hline$M F F$ & Hyperfused & $\begin{array}{l}\text { Mitochondrial encephalopathy with } \\
\text { OA }\end{array}$ & AR & DRP1 adaptor \\
\hline MIEF1 & Fragmented & DOA & $\mathrm{AD}$ & DRP1 adaptor \\
\hline GDAP1 & Fragmented or hyperfused & CMT with or without OA & $\mathrm{AD} / \mathrm{AR}$ & $\begin{array}{l}\text { DRP1 and FIS1 } \\
\text { regulation? }\end{array}$ \\
\hline
\end{tabular}

DOA, Dominant Optic Atrophy; AD, autosomal dominant; IMM, inner mitochondrial membrane; OA, Optic Atrophy; AR, autosomal recessive; CPEO, Chronic Progressive External Ophthalmoplegia; CMT, Charcot-Marie-Tooth neuropathy; HMSN, Hereditary motor and sensory neuropathy; MAMs, mitochondria-associated membranes; PS, phosphatidylserine.

\subsection{Mitochondrial Fusion Dysfunction as the Cause of DOA or "Plus" Syndromic Forms}

The main pathogenic mechanism underlying DOA is definitely an unbalance of mitochondrial fusion and fission, which may be directly affected, as in the case of mutations in OPA1 or other regulators of the dynamics machinery, or indirectly compromised, for example due to genetic defects of mitochondrial proteases involved in the OPA1 processing (Figure 2). Indeed, besides LHON, in most cases the degeneration of RGCs leading to optic atrophy is imputable to OPA1 dysfunctions. Moreover, OPA1 is the most frequent gene associated with isolated forms of DOA [9].

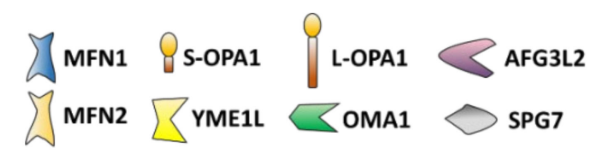

OUTER MEMBRANE FUSION

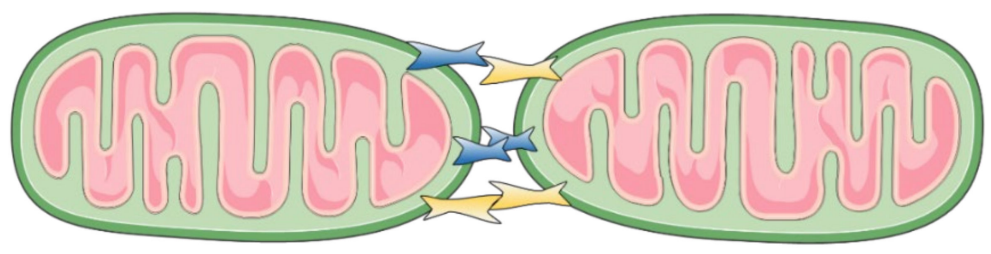

INNER MEMBRANE FUSION

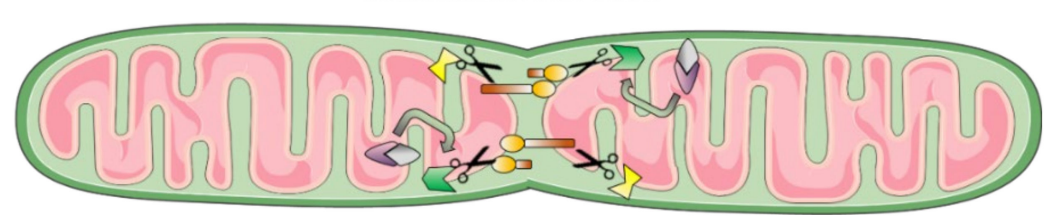

Figure 2. Proteins regulating mitochondrial fusion and associated with optic atrophy. A graphical representation of outer and inner membrane fusion with emphasis on proteins involved in the degeneration of optic nerve (see also Table 2). 
The major players of mitochondrial dynamics belong to the Dynamin Related Proteins (DRP) family, consisting of proteins able to remodel organelle membrane shape through GTP hydrolysis [60]. To date, in mammals, the only factor directly regulating fusion of the inner mitochondrial membrane (IMM) is OPA1, which co-operates with others DRPs in the outer mitochondrial membrane (OMM) (i.e., mitofusins) to produce a highly interconnected and tubular mitochondrial network [59]. Thanks to a mitochondrial targeting sequence (MTS) at the N-terminal, OPA1 is addressed to mitochondria, where it is embedded into the IMM through a transmembrane domain, exposing the GTPase domain in the intermembrane space (IMS) [61]. However, in addition to this unprocessed IMM-anchored form of OPA1 (long-OPA1, L-OPA1), also a soluble form of OPA1 (short-OPA1, S-OPA1) is present in the IMS, due to the proteolytic activity of two proteases located in the IMM: the YME1-Like Protein 1 (YME1L) and the Overlapping Activity With M-AAA Protease (OMA1) [62-64].

The presence of both L-OPA1 and S-OPA1 in a fine-tuned balance, together with the pro-fusion lipid cardiolipin, is required for the execution of the IMM fusion [65-68]. On the contrary, an increase of OMA1 activity due to stress conditions related to OXPHOS dysfunction leads to an imbalance towards S-OPA1 forms, with consequent fragmentation of the mitochondrial network $[63,69,70]$. Interestingly, OMA1 activity is regulated by different mechanisms, including autocatalysis $[70,71]$, or the degradation mediated by YME1L [72,73]. In addition, OMA1 activity is stimulated in the presence of defects in the mitochondrial protein synthesis quality control [74,75], in which a major role is played by the complex composed of AFG3 Like AAA ATPase 2 (AFG3L2) and paraplegin (encoded by SPG7 gene) proteases. Concordantly, AFG3L2 is also part, together with YME1L, of the IMM scaffolding protein Stomatin-Like Protein 2 (SLP2), and the Presenilin-Associated Rhomboid Like (PARL) protease, of a multi-protein complex called SPY, which negatively regulates OMA1 activity, thus stabilizing L-OPA1 and inducing the so-called "stressinduced mitochondrial hyperfusion" as a survival stress response [76,77]. The composition of L- and S-OPA1 within mitochondria is also dependent on the alternative splicing of OPA1 mRNA, producing eight different transcripts that are ubiquitous, but differentially expressed in cells and tissues [78]. In fact, while the cleavage site S1 (exon 5), specific for OMA1, is present in all OPA1 isoforms, the S2 (exon 5b) YME1L specific site is present exclusively in variants $4,6,7$, and 8 . Notably, a recent study has identified an additional cleavage site called S3 (exon $4 b$ ) specific for YME1L and proposed a pro-fusion role for S-OPA1 forms derived by this processing [68]. This means that, based on the combination of OPA1 isoforms expression, there will be a variable content in mitochondria of L- and S-OPA1 [69].

The presence of multiple isoforms may be also the explanation for the multiplicity of OPA1 functions in the mitochondrial homeostasis, such as the control of cristae morphology, OXPHOS function, and mtDNA maintenance. Remarkably, while for the IMM fusion isoforms generating both L- and S-OPA1 are required, the other functions may be performed indistinctly by L- or S-OPA1 [66,79].

In the majority of cases, OPA1 dominant mutations cause exclusively optic atrophy as clinical manifestation. However, about $20 \%$ of mutations, prominently missense mutations located in the GTPase domain, lead to syndromic phenotypes called DOA-plus that may include additional features such as deafness, peripheral neuropathy, myopathy with chronic progressive external ophthalmoplegia (CPEO), ataxia, Parkinsonism, and dementia. A few cases of biallelic OPA1 mutations, mostly compound heterozygous, have been reported to causing a severe disease known as Behr syndrome [9]. The pathogenic mechanism of OPA1 mutations has been extensively investigated in patients-derived cells or in animal models. It principally implicates the mitochondrial network fragmentation, cristae disorganization, OXPHOS deficiency [11,80-88], and mtDNA maintenance defects leading to multiple deletions in post-mitotic tissues [11,44,88,89]. The main pathological features, such as mitochondrial network fragmentation and reduced energetic capacity, have been also reproduced in induced pluripotent stem cell (iPSC)-derived dopaminer- 
gic neurons from patients carrying OPA1 mutations associated with Parkinsonism and DOA $[90,91]$. In this model, neuronal axons exhibited a severe depletion in the number of mitochondria, which showed also reduced motility, especially in the anterograde direction towards the synaptic terminals [92]. Moreover, enhanced autophagy and mitophagy have been documented in fibroblasts from patients carrying OPA1 mutations [88,93,94], as well as in RGCs isolated from Opa1 mutant mouse models [86,95-97]. Recently, Zaninello and colleagues demonstrated that, due to AMPK-dependent hyper-activation of mitophagy at axonal hillock, RGCs axons from Opa1 mutant mouse become depleted of mitochondria, resulting into dying back axonopathy, which ultimately hampers RGCs functioning and survival [97]. As a consequence of OPA1 deficiency, also the metabolomics and lipidomics profiles are altered in either DOA or DOA plus patients, as well as in cellular and mouse models of DOA. Alterations of purine metabolism (xanthine, hypoxanthine, and inosine), lipid metabolism (1-oleyl-rac-glycerol, rac-glycerol-1-myristate and glycerate, phosphocholine, and choline), and of few aminoacids (cystine, aspartate, glutamic acid, and urocanate) have been described in plasma from patients carrying OPA1 mutations [98]. Concordantly, variations in several phospholipids concentration have been reported in mouse embryonic fibroblasts (MEF) Opa1 ${ }^{-/-}$[99], MEF Opa1 $1^{-/-}$expressing different OPA1 mutants [100], and in the Opa $1^{\text {delTTAG/+ }}$ mouse model, specifically in the optic nerve and in plasma [101]. Thus, while alterations in purine metabolism and reduced glutamic acid are recurrent in mitochondrial diseases or in the presence of ATP depletion [102-105], changes in phospholipids, confirmed in three different models, may be the effect of mitochondrial membrane remodeling due to OPA1 dysfunction, in particular the defective mitochondrial fusion.

In the last years, thanks to next generation sequencing (NGS), novel genes have been found associated with optic atrophy, many of which modulating OPA1 activity, i.e., AFG3L2 and YME1L. Mutations in AFG3L2 and SPG7 have been initially identified as the cause of spinocerebellar ataxia type 28 (SCA28) and spastic ataxia type $5[106,107]$, and hereditary spastic paraplegia type- 7 (HSP7) [108], respectively. More recently, mutations in both these genes have been reported in patients affected by DOA or syndromic diseases with optic atrophy, also including Parkinsonism [109-113]. As described above, dysfunctional AFG3L2-paraplegin complex triggers a stress response orchestrated by OMA1 activation $[74,75]$, which, in turn, enhances OPA1 processing leading to an imbalance towards the soluble forms of OPA1 and mitochondrial fragmentation. Accordingly, this has been confirmed in fibroblasts derived from patients carrying AFG3L2 mutations in the ATPase domain and affected by DOA $[109,111,112]$. Interestingly, patients carrying biallelic SPG7 mutations showed hyperfused mitochondria, in contrast to what observed in AFG3L2 mutant fibroblasts [114].

Concerning the two proteases of OPA1, while mutations in OMA1 have not been associated with human disease yet, homozygous mutations in YME1L have been reported in four patients from a consanguineous Saudi Arabian family presenting an infantile-onset mitochondriopathy with optic atrophy [115]. This mutation impaired the maturation of YME1L, leading to degradation of the mutant protein, and consequently to the proteolysis of its targets PRELI Domain Containing 1 (PRELID1), a lipid transfer protein for phosphatidic acid in the IMS, and OPA1. Fibroblasts derived from these patients showed a fragmented mitochondrial network and reduced cell proliferation. These results are coherent with what observed in the mouse model [116,117] and MEF [64,72], where loss of Yme1l accelerates the processing of L-OPA1 by OMA1 with consequent mitochondrial fragmentation. Since YME1L is also involved in the phospholipid signaling dependent on the phosphatidic acid phosphatase LIPIN1 and the Mechanistic Target of Rapamycin 1 (mTORC1) [118], alterations in the lipidomics profile of YME1L mutant patients may also occur, similarly to what observed for OPA1 mutations; however, this aspect awaits to be evaluated.

The execution of mitochondrial fusion, as mentioned above, requires the coordination of two distinct processes, the outer and inner membranes fusion. The DRPs in the outer 
membrane ensuring this process are Mitofusins (i.e., MFN1 and MFN2), large homologous proteins with highly similar structures: the GTPase domain, transmembrane domains that are inserted in the OMM, and two heptad repeat domains (HR1 and HR2) exposed in the cytosol that allow homotypic and heterotypic interactions between MFNs located on different mitochondria. The tethering of juxtaposing mitochondria trough trans interactions mediated by HR2 domains represents the first step of OMM fusion. Then, the GTP hydrolysis promotes MFNs conformational change mediating mitochondria-mitochondria anchoring and fusion [59]. Although both MFN1 and MFN2 are fusion competent proteins $[119,120]$, MFN2 is less efficient in tethering mitochondria, possibly due to lower GTPase activity compared to MFN1 [121]. Interestingly, MFN2 is also enriched at MAMs, the ER-mitochondria interface essential for efficient mitochondrial $\mathrm{Ca}^{2+}$ uptake and lipids transfer between the two organelles [122-125].

Mutations in MFN2 cause the axonal form of Charcot-Marie-Tooth neuropathy (CMT2A) [126], either with dominant or recessive transmission and with the co-occurrence in some cases of optic atrophy $[9,127,128]$. The molecular pathogenesis of MFN2 mutations in CMT2A remains unclear, since contradictory results have been reported. Altered mitochondrial distribution and bioenergetics defects have been described in mice overexpressing in neurons a pathogenic mutation in MFN2 associated with CMT2A [129]. In mice overexpressing mutant MFN2 in dorsal root ganglia, mitochondrial transport, distribution, and morphology within the axons were significantly compromised, however, bioenergetics defects were absent $[130,131]$. While Mfn2-deficient MEF stably expressing mutant MFN2 exhibited slight mitochondrial fragmentation and increased susceptibility to oxidative stress [132], patient-derived fibroblasts carrying heterozygous MFN2 mutations showed no alterations of mitochondrial network, together with absence of defective mitochondrial morphology and abundance, or mtDNA depletion [133]. On the contrary, fibroblasts from patients carrying biallelic MFN2 mutations showed increased mitochondrial fusion [134]. Cytochrome c oxidase (COX) deficiency and mtDNA depletion has been observed in both fibroblasts and skeletal muscle from patients with heterozygous mutations [135]. CMT2A iPSC-derived motor neurons exhibited decreased mitochondrial content, perinuclear positioning of mitochondria and enhanced mitophagy [136]. Instead, defective ER-mitochondria contacts has been coherently reported in patients' fibroblasts, in MEF overexpressing mutant MFN2, in mouse primary neurons and, in vivo, in a mouse model of CMT2A [137,138]. As a consequence of the MAM alterations, ER stress, calcium handling, and phospholipids abnormalities have been described in these models. Thus, it turns out that CMT2A may be caused by defective MAMs-correlated pathways rather than defective fusion, possibly due to the compensatory effect of MFN1 activity.

Although optic atrophy has never been reported, mutations in the Misato Homolog 1 (MSTO1) gene, encoding for a pro-fusion protein, are causative for syndromic diseases characterized by muscular dystrophy, cerebellar atrophy, and pigmentary retinopathy [139-142]. Patient-derived fibroblasts showed mitochondrial network fragmentation and, interestingly, mtDNA depletion with nucleoids alterations [139,141].

\subsection{Mitochondrial Fission Dysfunction as the Cause of DOA and Syndromic Forms}

In analogy to fusion, mitochondrial fission is a process consisting of multiple sequential steps, but leading to the opposite result of scission of one mitochondrion into two daughter mitochondria.

A crucial event for mitochondrial fission is the recruitment of the cytosolic GTPase Dynamin-related protein 1 (DRP1) on the OMM and its oligomerization to form a constriction ring [59]. DRP1 is a highly conserved protein presenting four domains: the N-terminal GTPase domain, the middle domain, the variable domain, and the GTPase effector domain in C-terminal [143]. The absence of phospholipids-binding domains in DRP1 structure implies that its localization on the OMM requires adaptors proteins: the mitochondrial fission factor (MFF), the mitochondrial dynamics proteins of $49 \mathrm{kDa}$ (MID49) and $51 \mathrm{kDa}$ (MID51), and the Mitochondrial Fission 1 Protein (FIS1) [144], although a direct role for the 
latter as DRP1-receptor in mammals is still ambiguous [60]. DRP1 localizes on the OMM in specific areas, where ER and actin had previously wrapped the membrane generating pre-constriction sites $[145,146]$. This process allows the narrowing of the mitochondrial diameter and the formation of a DRP1-oligomeric ring-like structure surrounding the mitochondrion and enhancing the membrane constriction through GTP hydrolysis [147]. Remarkably, the ER-mitochondria contacts, which will determine the future scission sites, co-localize with replicating mtDNA nucleoids, thus ensuring the segregation of mtDNA in the newly formed mitochondria [21,148]. The ER-bound inverted-formin 2 (INF2) and the mitochondrial anchored formin-binding Spire1C cooperate to promote actin assembly at the ER-mitochondria contact sites, required for mitochondrial constriction $[146,149,150]$. Other proteins regulating the actin cytoskeleton are involved in this mechanism, including Myosin IIA, cofilin, cortactin, and Septin 2 [151-154]. Although DRP1 is essential for the first phases of mitochondrial fission, it may be not able to complete the scission of the mitochondrion [155], suggesting the involvement of other proteins. Recently, it has been demonstrated that Dynamin 2 (DNM2) acts downstream of DRP1 and it may be responsible for the final step of division [156]. Direct actors of the IMM constriction during mitochondrial fission have not been identified yet. However, a major role may be played by $\mathrm{Ca}^{2+}$ influx from ER to mitochondria at fission sites leading to IMM constriction before DRP1 recruitment on the OMM, as demonstrated by two recent studies [157,158]. Interestingly, fission of IMM may be promoted by increased levels of S-OPA1, as generated by a calcium-dependent leak in mitochondrial membrane potential and consequent OMA1 activation [157].

Dysfunction of mitochondrial fission, as much as mitochondrial fusion, has deleterious effects on neuronal cell homeostasis, being indeed associated with optic atrophy and neurodegeneration (Figure 3).

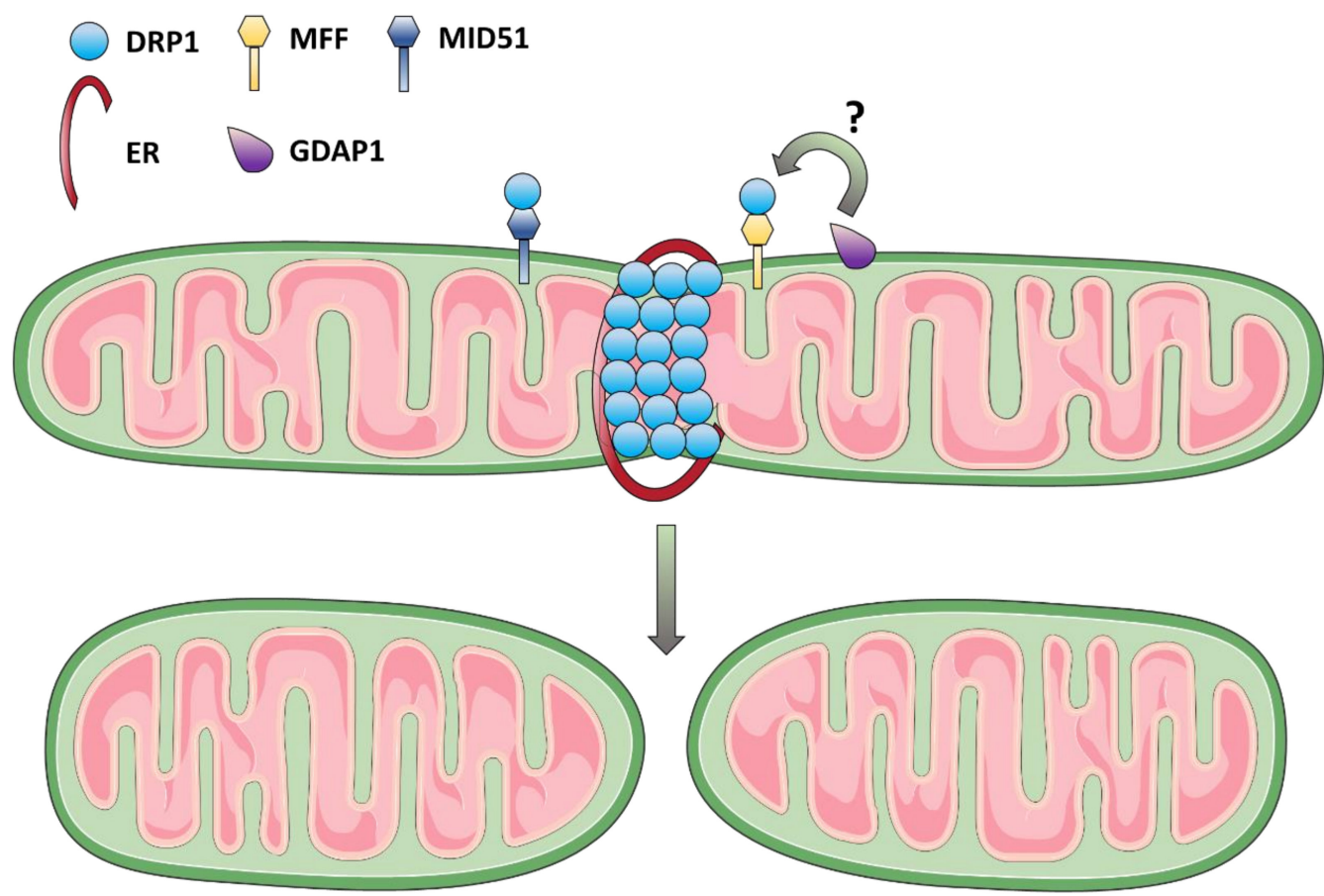

Figure 3. Proteins regulating mitochondrial fission and associated with optic atrophy. A graphical representation of the fission process, where the proteins involved in the degeneration of optic nerve are shown (see also Table 2).

In 2007, a case of lethal encephalopathy, which included optic atrophy in the clinical features, has been reported as caused by a de novo heterozygous dominant-negative mutation in DRP1. Patient fibroblasts showed hyperfusion of both peroxisomes and mi- 
tochondria, with depletion of peroxisomes and a few mitochondria displaying increased size and localization in the perinuclear region [159]. This phenotype closely resembled that observed in cells silenced for DRP1 or overexpressing a dominant-negative DRP1 mutant [155,160-163]. Additional cases of encephalopathy with variable clinical phenotypes caused by DRP1 mutations, frequently de novo, have been reported thereafter [164-169], including two families with autosomal recessive inheritance $[170,171]$. All studies of patient fibroblasts showed, hyperfused and giant/balloon-like mitochondria, together with peroxisomal abnormalities. In one study, autophagy has also been investigated, revealing a defective mitochondrial turnover due to mitochondrial fission dysfunction [169]. Besides these complex and severe disorders, dominant DRP1 mutations are also the cause of isolated optic atrophy undistinguishable from OPA1-DOA, as described by Gerber and colleagues. However, in these cases no alterations in the peroxisomal network were observed [172].

Similarly, mutations in the MFF gene have also been associated with autosomal recessive encephalopathy, again characterized by the presence of optic atrophy, and abnormal elongation of both mitochondrial and peroxisomes with diffuse cytoplasmic localization of DRP1 in patient fibroblasts [173,174]. In addition to MFF, another DRP1 adaptor, MID51 (MIEF1 gene), has been recently associated with a form of late-onset optic atrophy. MID51 mutant proteins expressed in HeLa cells decreased the mitochondrial fusion events and fragmented the mitochondrial network [175].

Ganglioside Induced Differentiation Associated Protein 1 (GDAP1), a glutathione S-transferase enzyme that seems to be a regulator of mitochondrial fission, although with still unclear mechanism of action $[176,177]$, is associated with a form of CMT occasionally presenting also optic atrophy $[178,179]$. Interestingly, overexpression of GDAP1 induces alterations of mitochondria distribution within the cell with a marked perinuclear localization [180], as already observed for DRP1 knockdown [155,160,162,163] or MFN2mutant [136]. Concordantly, GDAP1 is an OMM protein enriched in MAMs, where it interacts with two proteins involved in mitochondrial trafficking, the Ras-Related Protein Rab-6B (RAB6B) and caytaxin [181]. A recent study demonstrated that GDAP1 deficiency disrupts mitochondrial axonal transport in both anterograde and retrograde traffic and also affects mitochondrial bioenergetics and $\mathrm{Ca}^{2+}$ homeostasis [182], confirming previous evidence [181,183].

Other factors involved in the mitochondrial fission process have been linked to human diseases, such as MID49, associated with mitochondrial myopathy [184], DNM2, associated with centronuclear myopathy [185], Charcot-Marie-Tooth neuropathy type $2 \mathrm{M}$ with neutropenia and early-onset cataract $[186,187]$ and lethal congenital contracture syndrome [188], and INF2, associated with focal segmental glomerulosclerosis [189] and Charcot-Marie-Tooth disease with glomerulopathy [190]. Thus far, optic neuropathy has not been reported in association with these genes.

\section{Mitochondria-Associated Membranes: The Case of Wolfram Syndrome and More}

MAMs are dynamic structures regulating several intracellular pathways, such as calcium homeostasis, lipid synthesis and inter-organelles trafficking, mitochondrial dynamics, autophagy, and apoptosis [125]. These contacts are transitory juxtapositions of ER and mitochondria, separated by a distance of 10-30 nm [191], occurring without membrane fusion. It is plausible that these structures are generated through the action of specific proteins forming a bridge and tethering the two organelles [192]. In yeast, the physical connection between ER and mitochondria seems to be mediated by the ER-mitochondria encounter structure (ERMES) complex, encompassing two OMM proteins (Mdm10 and Mdm34), one protein located in the ER (Mmm1), and one in the cytosol (Mdm12) [193]. Although an ERMES equivalent complex has not been identified in mammalian cells, MFN1 and MFN2 heterodimers may mediate the tethering of ER and OMM at MAM sites [122]. Other proteins enriched in MAMs have been proposed for carrying out this function, such as DRP1 [145], the mitochondrial ubiquitin ligase, MITOL [194], the voltage-dependent 
anion channel, VDAC1 [195], and the phosphofurin acidic cluster protein 2, PACS-2 [196]. However, further investigations are needed to elucidate this aspect in mammals.

\subsection{MAMs Function in Calcium and Lipids Homeostasis, Autophagy, and Apoptosis}

The association of ER and mitochondria allows the exchange of molecules that are fundamental for several cellular processes. Intracellular $\mathrm{Ca}^{2+}$ is stored within the ER, which, under specific conditions, is released and captured by mitochondria. This process takes place at the MAM interface, and is mainly mediated by the inositol tri-phosphate receptors (IP3Rs) [197,198]. Moreover, different chaperone proteins of the ER can bind $\mathrm{Ca}^{2+}$, controlling its storage within ER and its flow upon stimulation of IP3Rs. For example, after ligand stimulation, IP3Rs directly interact with VDAC1 in the OMM through the chaperone glucose-regulated protein 75 (GRP75) $[195,199]$. Similarly, the SIGMA-1 receptor forms $\mathrm{a} \mathrm{Ca}^{2+}$ sensitive complex with the chaperone glucose-regulated protein 78 (GRP78/BiP), which regulates the degradation of IP3Rs upon $\mathrm{Ca}^{2+}$ depletion in the ER [200]. Interestingly, the same chaperones are upregulated in the unfolded protein response (UPR), following ER stress [201]. Once released from ER, $\mathrm{Ca}^{2+}$ can be taken up by mitochondria passing the OMM through VDAC1 and then imported in the matrix through the IMM mitochondrial calcium uniporter (MCU) [202,203]. The mitochondrial calcium influx and OXPHOS are extremely coordinated processes. The principal driving force for the mitochondrial calcium influx is the negative membrane potential in the matrix generated by the respiratory chain. At the same time, intramitochondrial calcium boosts ATP production by OXPHOS, necessary for the functioning of calcium pumps on the plasma membrane (PMCA) and on the Sarco/endoplasmic reticulum (SERCA) [204]. Moreover, the activity of three enzymes belonging to the Krebs cycle, isocitrate dehydrogenase (ICDH), oxoglutarate dehydrogenase $(\mathrm{OGDH})$, and pyruvate dehydrogenase $(\mathrm{PDH})$, is regulated by mitochondrial calcium, which boosts the production of NADH to sustain OXPHOS $[205,206]$. In physiological conditions, the uptake of calcium is transitory and its efflux is regulated by the calcium antiporter channels [207]. However, in pathological conditions, mitochondrial calcium overload triggers an increase in ROS production, which, in turn, determines the opening of the mitochondrial permeability transition pore (mPTP), loss of membrane potential, release of cytochrome $c$, and ultimately leads to cell death [204]. Interestingly, mitochondrial calcium also regulates the secretion of several hormones from endocrine cells, such as insulin from pancreatic $\beta$-cells $[208,209]$.

Other molecules transferred from ER to mitochondria, and vice versa through MAMs, are phospholipids, major components of the mitochondrial membranes and essential for the cristae architecture, thus impinging on the assembly of respiratory complexes in the IMM, and for mitochondrial morphology. MAMs are enriched in proteins deputed to lipid transfer and in enzymes implicated in lipid synthesis. For example, cardiolipin and phosphatidylethanolamine (PE), both crucial for mitochondrial membranes fusion, are synthesized in mitochondria starting from a major precursor deriving from ER, phosphatidic acid (PA). Through two different pathways, PA gives rise to PS and phosphatidylinositol (PI) on the ER side, whereas a series of reactions in the IMM transform PA in cardiolipin, which remains within mitochondria, primarily in the IMM. On the contrary, PS is imported in mitochondria and converted in PE, which, in turn, is transferred to the ER to generate PC, again re-imported within the mitochondria $[210,211]$. Protein complexes at the MAM sites mediate the inter-organelles travel of PA, PS, and PC. For example, in mammalian cells the complexes PRELID1/TP53 Regulated Inhibitor Of Apoptosis 1 (TRIAP1) and PRELID3b/TRIAP1 may mediate the transfer of PA and PS, respectively [212,213]. Recently, it has been demonstrated that Mfn2 binds and transfers phosphatidylserine (PS) across mitochondria-ER contact sites [214]. STARD7, steroidogenic acute regulatory protein (StAR)-related lipid transfer (START) protein, mediates the trafficking of phosphatidylcholine to mitochondria $[215,216]$ and intramitochondria [217].

Remarkably, when exposed in the OMM, cardiolipin participates in the execution of programmed cell death interacting with cytochrome $c$, Bid and caspase-8 [218]. Similarly, 
the PRELID1/TRIAP1 complex exerts anti-apoptotic function through the control of CL synthesis in the IMM [212]. Moreover, MAMs contains a few enzymes regulating the ceramides metabolism, suggesting that a pool of these pro-apoptotic lipids resides at the ER-mitochondria contacts [219]. Thus, MAMs are implicated in the cell death program, not only through the regulation of calcium fluxes, but also through lipid synthesis and trafficking.

Lastly, MAMs might provide lipid and membranes for the autophagosome formation during autophagy [220]. The process of autophagosome formation initiates from PI synthase-enriched sites in the ER, thus requiring PI in the first steps of autophagy [22]. This is corroborated by the presence of several autophagic proteins at MAMs during starvation, a known stimulus for autophagy. Moreover, the microtubule associated protein light chain 3 (LC3) needs to be conjugated with PE, probably derived from mitochondria, to promote autophagosome elongation and cargo sequestration [221].

\subsection{MAMs Dysfunction as The Cause of Optic Neuropathy and Neurodegenerative Syndromes}

MAMs dysfunction is an emergent pathogenic mechanism in the field of neurodegeneration, which includes also optic neuropathy (Figure 4 and Table 3). As discussed above, MFN2 mutations cause CMT peripheral neuropathy, with co-occurrence of optic atrophy. Moreover, MFN2 mutations have deleterious effects on MAMs processes, such as loss of ER-mitochondria contacts or greater inter-organellar distances, activation of UPR, intracellular calcium mishandling, defective PE and PS synthesis, increased production of cholesteryl ester (CE) with accumulation of lipid droplets [137,138]. This latter lipid is in fact produced by the enzyme acyl-CoA:cholesterol acyltransferase 1 (ACAT1), enriched in MAMs, and then stored in the lipid droplets in cytoplasm. Very rarely, MFN2 homozygous mutations have been reported in patients with multiple lipomatosis and neuropathy [222-224], linking MFN2 with lipid metabolism possibly thorough its role in MAMs organization.
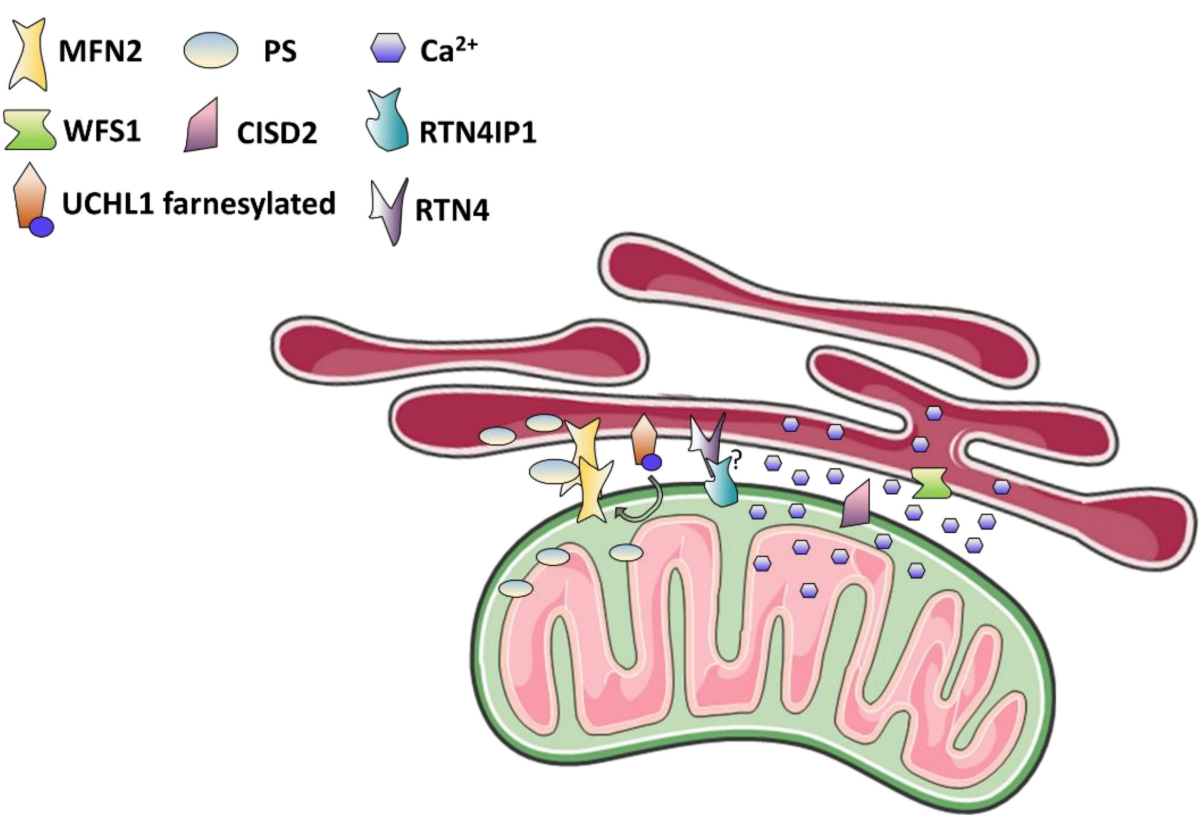

Figure 4. Optic atrophy is related to altered function of several MAMs proteins. A graphical representation of MAMs structure where proteins involved in the degeneration of optic nerve are shown (see also Table 3). PS, phosphatidylserine. 
Table 3. Main nuclear genes associated with mitochondria-associated membranes dysfunction leading to optic atrophy.

\begin{tabular}{|c|c|c|c|c|}
\hline Gene & Effect on MAMs Function & Disease & Inheritance & Protein Function \\
\hline MFN2 & $\begin{array}{l}\text { Reduced ER-mitochondria } \\
\text { contacts; UPR activation; } \\
\mathrm{Ca}^{2+} \text { and lipids mishandling; } \\
\text { altered autophagy }\end{array}$ & $\begin{array}{c}\text { CMT with or without OA } \\
\text { HMSN } \\
\text { Lipomatosis and neuropathy }\end{array}$ & $\begin{array}{l}\mathrm{AD} / \mathrm{AR} \\
\mathrm{AD} \\
\mathrm{AR}\end{array}$ & $\begin{array}{l}\text { OMM fusion; MAMs } \\
\text { formation; PS transfer }\end{array}$ \\
\hline UCHL1 & $\begin{array}{l}\text { Reduced ER-mitochondria } \\
\text { contacts; } \mathrm{Ca}^{2+} \text { mishandling }{ }^{1}\end{array}$ & Spastic paraplegia with OA & $\mathrm{AR}$ & $\begin{array}{c}\text { Protein } \\
\text { deubiquitination }\end{array}$ \\
\hline RTN4IP1 & Unknown & $\begin{array}{c}\text { OA with or without ataxia, ID, and } \\
\text { epilepsy }\end{array}$ & $\mathrm{AR}$ & $\begin{array}{l}\text { CI assembly; RTN4 } \\
\text { interactor }\end{array}$ \\
\hline WFS1 & $\begin{array}{l}\text { Reduced ER-mitochondria } \\
\text { contacts; } \mathrm{Ca}^{2+} \text { mishandling }\end{array}$ & $\begin{array}{c}\text { WS1 } \\
\text { Isolated cataract, or diabetes or } \\
\text { deafness } \\
\text { Isolated OA } \\
\text { WS-like }\end{array}$ & $\begin{array}{l}\text { AR } \\
A D \\
A R \\
A D\end{array}$ & $\begin{array}{l}\mathrm{Ca}^{2+} \text { homeostasis; UPR } \\
\text { and ER stress } \\
\text { regulation; insulin } \\
\text { biosynthesis }\end{array}$ \\
\hline CISD2 & $\begin{array}{l}\text { Increased ER-mitochondria } \\
\text { contact; mitochondrial } \mathrm{Ca}^{2+} \\
\text { overload; enhanced ROS }\end{array}$ & WS2 & $\mathrm{AR}$ & $\begin{array}{l}\mathrm{Ca}^{2+} \text { homeostasis; } \\
\text { anti-oxidant activity }\end{array}$ \\
\hline
\end{tabular}

${ }^{1}$ Effects of UCHL1 KD in human cells. UPR, unfolded protein response; CMT, Charcot-Marie-Tooth; OA, optic atrophy; HMSN, Hereditary motor and sensory neuropathy; $\mathrm{AD}$, autosomal dominant; $\mathrm{AR}$, autosomal recessive; OMM, outer mitochondrial membrane; MAMs, mitochondria-associated membranes; PS, phosphatidylserine; ID, intellectual disability; WS1, Wolfram syndrome type 1; WS2, Wolfram syndrome type 2; ROS, reactive oxygen species.

Several studies underline this function of MFN2, which was confirmed in lung alveolar type 2 epithelial cells [225], and in conditional Mfn2 knockout adipose-specific mice, demonstrating that Mfn2 mediates mitochondria-lipid droplet interactions and influences lipolytic processes [226]. Furthermore, as discussed above, MFN2 may direct the PS transfer from ER to mitochondria, and alterations of this function leads to hepatic steatosis in mice [214]. Moreover, reduction of MFN2 expression also impairs autophagy and mitophagy, possibly as a consequence of MAMs disruption [227,228], and MFN2 mutations have been reported to enhance mitophagy in motor neurons [136]. Lipid alterations, autophagy/mitophagy dysfunctions and mtDNA depletion are also related to the lysocardiolipin acyltransferase 1 (ALCAT1), enriched in MAMs, which controls cardiolipin remodeling and MFN2 expression [229-231].

$\mathrm{Ca}^{2+}$ mishandling and MAMs alterations may be involved in the pathogenic mechanism of two other genes causing complex syndromes with optic atrophy, i.e., Ubiquitin C-Terminal Hydrolase L1 (UCHL1) and RTN4IP. Homozygous or compound heterozygous mutations in the UCHL1 gene, encoding for a neuronal specific deubiquitinating enzyme, have been associated to early-onset spastic paraplegia and optic atrophy, with additional variable features such as peripheral neuropathy, cerebellar ataxia, myokymia, and cognitive impairment $[232,233]$, a phenotype resembling that of Uchl1 knockout mice [234,235]. However, in the most recent $\mathrm{KO}$ mouse model optic atrophy was absent, as examined at four months of age [235]. The molecular basis of the neurodegeneration induced by UCHL1 dysfunction has not been investigated yet in patients-derived cells. However, a recent study described a close relationship between UCHL1 and MFN2, demonstrating that loss of UCHL1 impairs mitochondrial morphology, alters the mitochondrial network, oxygen consumption, and, in parallel, reduces ER-mitochondria contact sites and mitochondrial $\mathrm{Ca}^{2+}$ uptake [236]. Interestingly, UCHL1, when farnesylated, is associated to ER membranes and, concordantly, it has been detected in MAMs fractions of mouse brain tissues $[237,238]$. In addition, UCHL1 deficiency and accumulation of polyubiquitinated proteins have been reported in $\beta$-cells from type 2 diabetes affected patients, thus connecting again MAMs dysfunction to diabetes [239].

Mutations in the RTN4IP1 gene are associated with either recessive isolated optic atrophy or severe early-onset encephalopathy [57,58]. RTN4IP1 is a mitochondrial protein with still unknown function. However, it interacts with RTN4 (also known as NOGO), an ER protein enriched in MAMs [57,237], which regulates dendrites formation and exten- 
sion in the developing central nervous system [240]. Smaller optic disc size in patients carrying RTN4IP1 mutation and the concordant phenotype of small eyes lacking RGCs in knockdown zebrafish are both indicative of an abnormal development of the optic nerve, possibly due to loss of interaction with RTN4 [57]. Enzymatic activity of complex I and IV was found defective in RTN4IP1 patients-derived fibroblasts, as well as complex I assembly. Mitochondrial network fragmentation has been reported in some but not in all fibroblast cell lines studied [57,58], probably as a secondary effect of mitochondrial dysfunction. Last, RTN4IP1 mutant fibroblasts showed increased sensitivity to UV light-induced damage, suggesting that also the continuous exposure of RGCs to visible light may be deleterious in the presence of defective RTN4IP1 [57].

\subsection{Wolfram Syndrome: The MAMs Perspective}

Another example of optic atrophy related to MAMs dysfunction is Wolfram syndrome (WS1), an autosomal recessive multi-systemic disease characterized by diabetes insipidus, diabetes mellitus, optic atrophy, deafness, and a wide range of additional neurological features, such as cerebellar ataxia, peripheral neuropathy psychiatric disorder, and epilepsy [241]. The genetic cause of WS is the presence of biallelic mutations in the Wolfram syndrome 1 (WFS1) gene, encoding for Wolframin, a protein located in the ER membranes and involved in calcium homeostasis and in the UPR [242-246]. Heterozygous mutations in WFS1 have also been associated with non-syndromic diseases characterized by isolated hearing loss, diabetes or congenital cataract, and with Wolfram-like syndrome, characterized by progressive hearing impairment, diabetes mellitus, and optic atrophy [247]. Moreover, cases of isolated optic atrophy have been reported as due to biallelic mutations in this gene [248]. A partial overlapping disease, Wolfram syndrome type 2 (WS2), is caused by recessive mutations in the CDGSH Iron Sulfur Domain 2 (CISD2) gene, encoding for a MAM localized protein (also known as Miner1 or ERIS) that, similarly to WFS1, regulates the UPR and calcium homeostasis [249-251]. From a clinical perspective, WS2 differs from WS1 for the lack of diabetes insipidus and psychiatric features, and the presence of platelet aggregation resulting in upper gastrointestinal ulceration and bleeding [250,252] However, a case of homozygous CISD2 mutation associated with "classical" WS1 has been reported [253]. Interestingly, a proteomic study evidenced the presence of Wfs1 in the MAMs fraction isolated from mouse brain tissues [237], and we recently confirmed that WFS1 is enriched in the MAMs also in human cell lines [19]. These findings suggest that Wolfram syndrome, and associated optic atrophy, may be due to alterations in MAMs-related processes, as in CMT2A. According to this consideration, WS1 fibroblasts show reduced mitochondrial $\mathrm{Ca}^{2+}$ uptake driven by altered $\mathrm{Ca}^{2+}$ release from ER and altered ER-mitochondria contacts, whereas mitochondrial dynamics and morphology are not affected [18,19]. The increase in non-oxidative glycolysis, documented by high lactate levels in plasma of WS1 patients, in absence of defective mitochondrial respiration, and enhanced extracellular acidification rate (ECAR) in fibroblasts, may be related to a reduced activity of PDH, as regulated by mitochondrial $\mathrm{Ca}^{2+}$, and to diabetes [19]. The presence of a mitochondrial bioenergetics dysfunction is still unclear, since controversial results have been reported $[18,19]$. However, it is possible that, in the specific cell types affected in WS (neurons and pancreatic $\beta$-cells), the mitochondrial OXPHOS may be affected due to calcium mishandling. In fact, in neuronal cells from a Wfs1-knockout mouse altered mitochondrial trafficking, inhibition of mitochondrial fusion, and increased mitophagy have been described [254]. Similarly, altered calcium homeostasis due to loss of WFS1 causes cell death of pancreatic $\beta$-cells or in patient-derived neuronal progenitor cells through hyper-activation of calpain 2, a calcium dependent protease $[255,256]$. Furthermore, WFS1 promotes insulin biosynthesis and negatively regulates ER stress inhibiting DNA damage inducible transcript 3 (also known as CHOP)-mediated apoptosis in $\beta$-cells, ensuring the physiological function of these cells [257]. Consistent with MAMs dysfunction, ER stress have been documented in the retina from Wfs1-knockout mouse, showing increasing levels 
of UPR markers (BiP/GRP78, protein disulfide isomerase, and inositol-requiring enzyme 1 alpha) [258], and it is possibly caused by ER permeabilization [259].

WFS1 and CISD2 share similar functions and their genetic alterations cause similar diseases. However, these two proteins probably do not work in synergy, since they are not interactors, and are structurally different, being WFS1 a glycoprotein and CISD2 a redoxactive $2 \mathrm{Fe} 2 \mathrm{~S}$ cluster protein $[249,251]$. ER stress and activated UPR have been observed in Cisd2- knockout mice and MEFs, as well as mitochondrial ultrastructural changes such as increased cristae density [251], also in the optic nerve [260]. Loss of Cisd2 induces a dramatic alteration of intracellular $\mathrm{Ca}^{2+}$ consisting in depletion of $\mathrm{ER} \mathrm{Ca}^{2+}$ storage that, as opposed to WFS1 dysfunction, leads to $\mathrm{Ca}^{2+}$ overload in mitochondria. Accordingly, the oxygen consumption rate is increased, possibly secondary to the activation of PDH by $\mathrm{Ca}^{2+}$, which boosts the conversion of pyruvate into acetyl-CoA and the production of OXPHOS substrates through the Krebs cycle [251]. Enhanced reactive oxygen and nitrogen species have also been reported in these models [251], confirming previous indications on CISD2 as a master regulator of life-span, possibly through its anti-oxidant activity [260]. Fibroblasts carrying a CISD2 missense mutation not affecting mRNA or protein expression confirmed the enhanced $\mathrm{Ca}^{2+}$ flux from ER to mitochondria, in addition to increase ERmitochondria contact sites and hyper-fusion of mitochondrial network. No ER stress was found, although the ER lumen was swollen. Moreover, patient-derived fibroblasts showed defective complex I and II activities and reduced ATP levels when grown in glucose-free galactose containing medium, a well-known stress condition that highlights mitochondrial bioenergetics defects [253]. Similarly to WFS1, CISD2 dysfunction induce cell death through calpain 2 activation, as demonstrated in knockdown neuronal and $\beta$-cells [256]. Lastly, myelin degeneration has been described in the axons of central (optic) and peripheral (sciatic) nerves, which seems to be mediated by increased autophagy [260]. Considering that abnormal white matter myelination has been described in a young WS1 patient and that ER stress and UPR are implicated in some inherited myelin disorders (for example Vanishing White Matter disease), Wolfram syndrome has also been proposed to be a neurodevelopmental disorder characterized by ER stress-mediated impairment of myelination [261,262].

\section{Other Emerging Mechanisms: From Oxidative Phosphorylation to Lipid Metabolism}

Additional genes have been implicated in the pathogenesis of optic atrophy, some of them converging on the same, often intercorrelated, pathways, such as mitochondrial morphology and cristae architecture, lipid metabolism, oxidative phosphorylation, and mtDNA maintenance (Figure 5).

Optic Atrophy 3 (OPA3) and Solute Carrier Family 25 Member 46 (SLC25A46) are associated with recessive inherited complex neurodegenerative disorders that include optic atrophy as a key feature (Costeff syndrome and CMT with cerebellar atrophy, respectively) [263-265]. Moreover, heterozygous mutations in OPA3 are responsible for DOA, isolated or presenting with cataract and/or hearing loss, and characterized by intraand interfamilial variability in the phenotypic expression [9,266,267]. Recently, a case of DOA with cataract and axonal neuropathy has also been reported [268]. Additionally, the phenotypic spectrum of SLC25A46 expanded, including the severe infantile Leigh-like encephalopathy [265], but also severe congenital ponto-cerebellar hypoplasia [269-271] and more recently optic atrophy and Parkinsonism [272], this latter case resembling some specific OPA1 mutations [73]. Both OPA3 and SLC25A46 proteins are located in mitochondria and have initially been described as mitochondrial fission regulators, since knockdown experiments or studies on patients-derived fibroblasts showed hyperfusion of mitochondrial network [264,265,273-275]. However, more recent findings suggest that both OPA3 and SLC25A46 may be involved in lipid homeostasis, and SLC25A46 controls mitochondrial cristae architecture through regulation of the mitochondrial contact site and cristae organizing system (MICOS) complex $[265,276,277]$. While the role of OPA3 in mitochondrial fission remains unclear, it has been recently demonstrated that SLC25A46 modulates 
oligomerization and stability of MFN1 and MFN2, resulting in increased mitochondrial fusion upon its loss [278]. OXPHOS dysfunctions have been described in both OPA3 and SLC25A46 patients' cells [82,264,265].

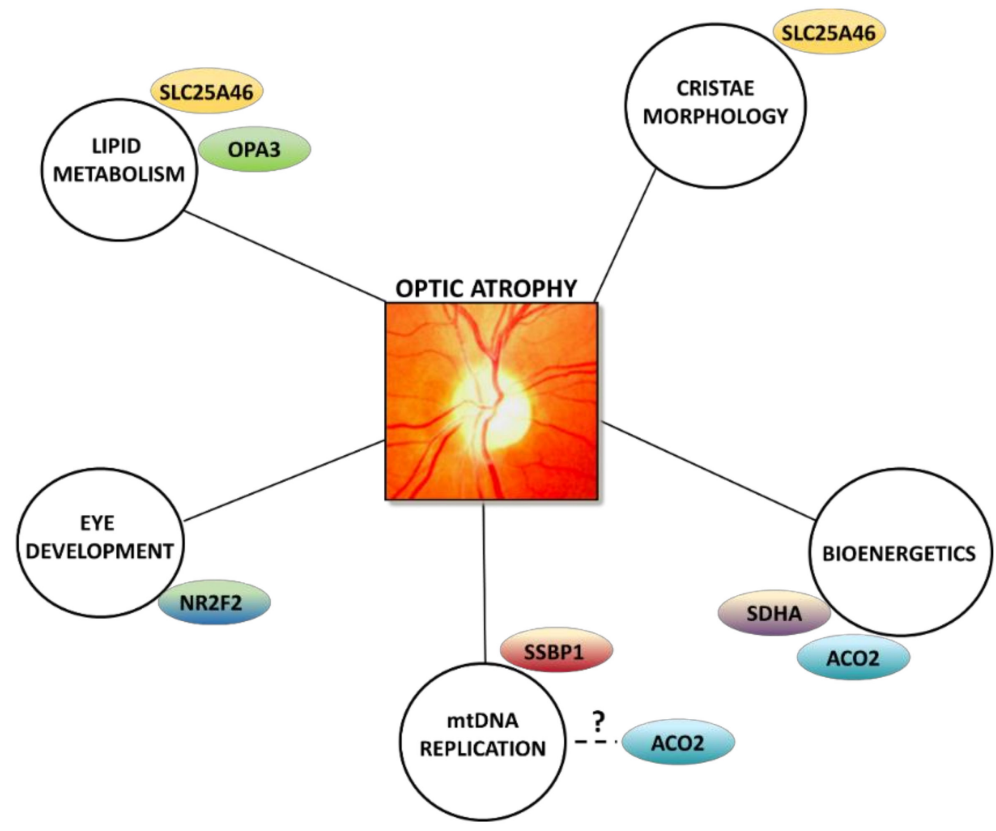

Figure 5. Additional pathways involved in optic atrophy. Schematic representation of different pathways converging on optic nerve degeneration, involving several genes associated with optic atrophy. A pale optic nerve head is shown at the center of the figure.

Alterations in ceramides and sphingomyelins, implicated in cell survival and biological membrane functioning, underlie the pathogenic mechanism of the Elongation Of Very Long Chain Fatty Acids 1 (ELOVL1) gene heterozygous mutations, leading to ichthyosis, hypomyelination, spastic paraplegia, deafness, and optic atrophy [279,280].

Depletion of mtDNA, and consequent OXPHOS dysfunction, due to SSBP1 dominant, but also recessive, mutations are the cause of optic atrophy with retinal abnormalities [12-14], in some cases complicated by deafness and renal disease leading to transplant [13]. Indeed, SSBP1 is essential for the correct replication of mtDNA, binding and stabilizing to the single strand of the displacement loop during mtDNA synthesis [281].

Complex II (succinic dehydrogenase, SDH) deficiency due to heterozygous mutations in the SDHA gene leads to bilateral optic atrophy, cerebellar atrophy, polyneuropathy, psychiatric involvement, and cardiomyopathy [282]. More recently, an additional case of childhood onset bilateral optic atrophy and cognitive impairment caused by a heterozygous mutation in SDHA has been described [283]. It should be noted that SDH is an enzyme acting both in the mitochondrial respiratory chain and in the Krebs cycle, coupling the oxidation of succinate to fumarate with the reduction of ubiquinone to ubiquinol.

Interestingly, Aconitase 2 (ACO2), another enzyme of the Krebs cycle that converts citrate into isocitrate, is responsible for both recessive and dominant optic neuropathy, isolated or occurring in syndromic forms with encephalopathy and cerebellar atrophy [284,285]. Interestingly, mtDNA depletion has been observed in patients' fibroblasts carrying a heterozygous ACO2 mutation leading to haploinsufficiency [285], congruent with another case of recessive neuromuscular disease due to compound heterozygous mutations in ACO2 [286].

Last, NR2F2, an orphan nuclear receptor ligand-activated transcription factor, is associated with the Bosch-Boonstra-Schaaf optic atrophy syndrome (BBSOSA), characterized by delayed development, moderate intellectual disability, and optic atrophy [287]. Mouse Nr2f2, also known as COUP-TFII, regulates eye development controlling the expression of 
several regulatory genes essential for early optic vesicle development [288]. Recently, it has been demonstrated that NR2F2 induces oxidative stress and represses several genes required for the maintenance of mitochondrial function and is elevated in dopaminergic neurons of Parkinson disease patients [289].

\section{Concluding Remarks and Future Directions}

Embracing a holistic view, the key pathological mechanisms underlying the common phenotypic outcome of optic atrophy here delineated, namely dysfunction of complex I, mitochondrial dynamics, and the inter-organelles dialog between ER and mitochondria, are, in turn, all interconnected, in fact also implicating mtDNA maintenance and OXPHOS efficiency, ROS production, lipid biosynthesis and membrane maintenance, and calcium handling (Figure 6). The gap of knowledge that needs to be further and rapidly filled, to truly impact these mechanisms by therapies, is how these pathways and molecular mechanisms translate into neuronal degeneration. It has been emphasized elsewhere the next complexity of applying these mechanisms to the specific cell types involved in the final outcome of neuronal degeneration [22]. These may include glial cells, such as oligodendrocytes providing the myelin wrapping to neuronal axons, but also the vascular tissue or the immune system, which may be implicated in the metabolic regulation and inflammatory responses.

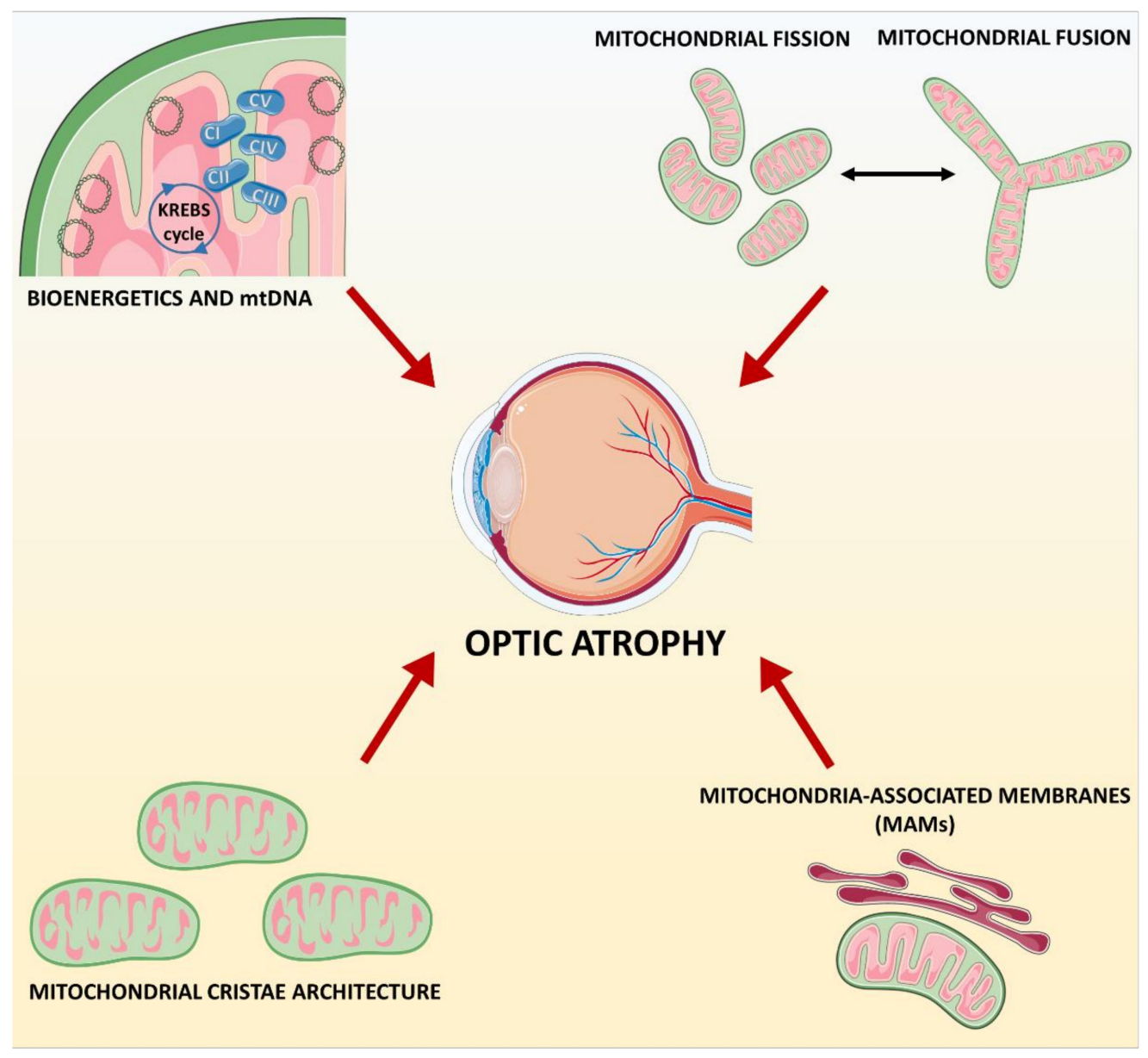

Figure 6. Molecular pathways behind inherited optic atrophy. Bioenergetics, mtDNA maintenance, mitochondrial dynamics, mitochondrial cristae morphology and MAMs are the principal interconnected pathways implicated in the degeneration of optic nerve.

Ultimately, the neuronal metabolism and architecture, which differs in neuronal subtypes, in particular considering the key target for optic neuropathies represented by 
RGCs, needs to be investigated by directly perturbing the pathologic mechanisms we have reviewed here. This is the ultimate basis to elaborate therapeutic strategies, and to reach this objective the future use of patient-derived reprogramed stem cells and differentiated cells or organoids is one of the innovative tools in addition to and complementing the traditional animal modeling of human diseases [290]. In the context of neuronal cells, key physiological activities, such as axonal transport, maintenance of the synaptic terminals, strict interaction with oligodendrocytes for myelin maintenance, just to name the most relevant, are all areas of research interest [1-4,23]. Extremely powerful approaches are nowadays available to reach these objectives, such as single cell multiomic analysis, as these may be dissected from organoids and/or human derived tissues when available [291], in conjunction with massive screening for compensatory mechanisms or for identifying effective drugs by CRISPR/Cas9-based technologies [292].

If we look at the pathogenic mechanisms here reviewed, we may already envisage some major areas for therapeutic strategies. As far it concerns strictly complex I, the recent elucidation of the structure and function of this multi-subunit very large enzyme opens the way to tailor drug approaches to the specific defects generated by the different mutations. Downstream consequences may be more relevant on defective bioenergetics or on ROS productions, potentially allowing for more specific interventions, such as metabolic rewiring [103]. Switching on mitochondrial dynamics, besides the possibility to modulate fusion or fission, this is profoundly imbricated with the homeostatic control of mitochondrial biogenesis, as well as with the removal of dysfunctional mitochondria by targeted autophagy [293]. As we emphasized in the previous sections, the inter-organellar communication through the MAM is also directly interconnected with mitochondrial dynamics, and offers another field of therapeutic intervention by modulating the calcium homeostasis. On top of all these possible approaches sits the offer to correct the genetic defects directly by gene therapy or gene editing, which provides a completely different level of therapeutic intervention [294]. The deep understanding of RGCs' specific developmental programs, in addition to their metabolic and physiological properties, may overcome the challenge of optic nerve regeneration. This ultimate goal will provide a cure to those patients who already suffered the neurodegeneration [295].

Author Contributions: Conceptualization, A.M. and V.C.; writing-original draft preparation, A.M. and V.C.; writing-review and editing, A.M. and V.C.; figures, A.M.; funding acquisition, V.C. All authors have read and agreed to the published version of the manuscript.

Funding: A.M. and V.C. are supported by the Italian Ministry of Health (Ricerca Corrente funding to the IRCCS Istituto delle Scienze Neurologiche di Bologna and the RF-2018-12366703 REORION grant). V.C. is supported by the Italian Ministry of University and Research (MUR) (PRIN-2017 20172T2MHH grant).

Institutional Review Board Statement: Not applicable.

Informed Consent Statement: Not applicable.

Data Availability Statement: Not applicable.

Acknowledgments: The Mitocon Onlus association for mitochondrial patients is acknowledged for its continuous support and effort.

Conflicts of Interest: The authors declare no conflict of interest.

\section{References}

1. Carelli, V.; la Morgia, C.; Valentino, M.L.; Barboni, P.; Ross-Cisneros, F.N.; Sadun, A.A. Retinal Ganglion Cell Neurodegeneration in Mitochondrial Inherited Disorders. Biochim. Biophys. Acta Bioenerg. 2009, 1787, 518-528. [CrossRef] [PubMed]

2. Yu-Wai-Man, P.; Votruba, M.; Burté, F.; la Morgia, C.; Barboni, P.; Carelli, V. A Neurodegenerative Perspective on Mitochondrial Optic Neuropathies. Acta Neuropathol. 2016, 132, 789-806. [CrossRef]

3. Carelli, V.; Ross-Cisneros, F.N.; Sadun, A.A. Mitochondrial Dysfunction as a Cause of Optic Neuropathies. Prog. Retin. Eye Res. 2004, 23, 53-89. [CrossRef] 
4. Yu-Wai-Man, P.; Griffiths, P.G.; Chinnery, P.F. Mitochondrial Optic Neuropathies—Disease Mechanisms and Therapeutic Strategies. Prog. Retin. Eye Res. 2011, 30, 81-114. [CrossRef] [PubMed]

5. Di Mauro, S.; Schon, E.A.; Carelli, V.; Hirano, M. The Clinical Maze of Mitochondrial Neurology. Nat. Rev. Neurol. 2013, 9, 429-444. [CrossRef] [PubMed]

6. Gorman, G.S.; Chinnery, P.F.; DiMauro, S.; Hirano, M.; Koga, Y.; McFarland, R.; Suomalainen, A.; Thorburn, D.R.; Zeviani, M.; Turnbull, D.M. Mitochondrial Diseases. Nat. Rev. Dis. Primers 2016, 2. [CrossRef] [PubMed]

7. Wallace, D.C. Mitochondrial Genetic Medicine. Nat. Genet. 2018, 50, 1642-1649. [CrossRef]

8. Rath, S.; Sharma, R.; Gupta, R.; Ast, T.; Chan, C.; Durham, T.J.; Goodman, R.P.; Grabarek, Z.; Haas, M.E.; Hung, W.H.W.; et al. MitoCarta3.0: An Updated Mitochondrial Proteome Now with Sub-Organelle Localization and Pathway Annotations. Nucleic Acids Res. 2021, 49, D1541-D1547. [CrossRef]

9. Lenaers, G.; Neutzner, A.; le Dantec, Y.; Jüschke, C.; Xiao, T.; Decembrini, S.; Swirski, S.; Kieninger, S.; Agca, C.; Kim, U.S.; et al. Dominant Optic Atrophy: Culprit Mitochondria in the Optic Nerve. Prog. Retin. Eye Res. 2020, 100935. [CrossRef]

10. Carelli, V.; Chan, D.C. Mitochondrial DNA: Impacting Central and Peripheral Nervous Systems. Neuron 2014, 84, 1126-1142. [CrossRef]

11. Amati-Bonneau, P.; Valentino, M.L.; Reynier, P.; Gallardo, M.E.; Bornstein, B.; Boissiere, A.; Campos, Y.; Rivera, H.; de la Aleja, J.G.; Carroccia, R.; et al. OPA1 Mutations Induce Mitochondrial DNA Instability and Optic Atrophy "plus" Phenotypes. Brain 2008, 131, 338-351. [CrossRef] [PubMed]

12. Jurkute, N.; Leu, C.; Pogoda, H.; Arno, G.; Robson, A.G.; Nürnberg, G.; Altmüller, J.; Thiele, H.; Motameny, S.; Toliat, M.R.; et al. SSBP1 Mutations in Dominant Optic Atrophy with Variable Retinal Degeneration. Ann. Neurol. 2019, 86, 368-383. [CrossRef] [PubMed]

13. Del Dotto, V.; Ullah, F.; di Meo, I.; Magini, P.; Gusic, M.; Maresca, A.; Caporali, L.; Palombo, F.; Tagliavini, F.; Baugh, E.H.; et al. SSBP1 Mutations Cause MtDNA Depletion Underlying a Complex Optic Atrophy Disorder. J. Clin. Investig. 2019, 130, 108-125. [CrossRef] [PubMed]

14. Piro-Mégy, C.; Sarzi, E.; Tarrés-Solé, A.; Péquignot, M.; Hensen, F.; Quilès, M.; Manes, G.; Chakraborty, A.; Sénéchal, A.; Bocquet, B.; et al. Dominant Mutations in MtDNA Maintenance Gene SSBP1 Cause Optic Atrophy and Foveopathy. J. Clin. Investig. 2019, 130, 143-156. [CrossRef] [PubMed]

15. Burté, F.; Carelli, V.; Chinnery, P.F.; Yu-Wai-Man, P. Disturbed Mitochondrial Dynamics and Neurodegenerative Disorders. Nat. Rev. Neurol. 2015, 11, 11-24. [CrossRef]

16. Maresca, A.; la Morgia, C.; Caporali, L.; Valentino, M.L.; Carelli, V. The Optic Nerve: A “Mito-Window" on Mitochondrial Neurodegeneration. Mol. Cell. Neurosci. 2013, 55, 62-76. [CrossRef]

17. Li, L.; Venkataraman, L.; Chen, S.; Fu, H. Function of WFS1 and WFS2 in the Central Nervous System: Implications for Wolfram Syndrome and Alzheimer's Disease. Neurosci. Biobehav. Rev. 2020, 118, 775-783. [CrossRef]

18. Angebault, C.; Fauconnier, J.; Patergnani, S.; Rieusset, J.; Danese, A.; Affortit, C.A.; Jagodzinska, J.; Mégy, C.; Quiles, M.; Cazevieille, C.; et al. ER-Mitochondria Cross-Talk Is Regulated by the Ca2+ Sensor NCS1 and Is Impaired in Wolfram Syndrome. Sci. Signal. 2018, 11. [CrossRef]

19. La Morgia, C.; Maresca, A.; Amore, G.; Gramegna, L.L.; Carbonelli, M.; Scimonelli, E.; Danese, A.; Patergnani, S.; Caporali, L.; Tagliavini, F.; et al. Calcium Mishandling in Absence of Primary Mitochondrial Dysfunction Drives Cellular Pathology in Wolfram Syndrome. Sci Rep 2020, 10, 4785. [CrossRef]

20. Krols, M.; van Isterdael, G.; Asselbergh, B.; Kremer, A.; Lippens, S.; Timmerman, V.; Janssens, S. Mitochondria-Associated Membranes as Hubs for Neurodegeneration. Acta Neuropathol. 2016, 131, 505-523. [CrossRef]

21. Lewis, S.C.; Uchiyama, L.F.; Nunnari, J. ER-Mitochondria Contacts Couple MtDNA Synthesis with Mitochondrial Division in Human Cells. Science 2016, 353. [CrossRef] [PubMed]

22. Nishimura, T.; Tamura, N.; Kono, N.; Shimanaka, Y.; Arai, H.; Yamamoto, H.; Mizushima, N. Autophagosome Formation Is Initiated at Phosphatidylinositol Synthase-enriched ER Subdomains. EMBO J. 2017, 36, 1719-1735. [CrossRef] [PubMed]

23. Carelli, V.; la Morgia, C.; Ross-Cisneros, F.N.; Sadun, A.A. Optic Neuropathies: The Tip of the Neurodegeneration Iceberg I Human Molecular Genetics I Oxford Academic. Available online: https:/ /academic.oup.com/hmg/article/26/R2/R139/4036433 (accessed on 6 February 2021).

24. Gerber, S.; Ding, M.G.; Gérard, X.; Zwicker, K.; Zanlonghi, X.; Rio, M.; Serre, V.; Hanein, S.; Munnich, A.; Rotig, A.; et al. Compound Heterozygosity for Severe and Hypomorphic NDUFS2 Mutations Cause Non-Syndromic LHON-like Optic Neuropathy. J. Med. Genet. 2017, 54, 346-356. [CrossRef]

25. Stenton, S.L.; Sheremet, N.L.; Catarino, C.B.; Andreeva, N.; Assouline, Z.; Barboni, P.; Barel, O.; Berutti, R.; Bychkov, I.O.; Caporali, L.; et al. Impaired Complex I Repair Causes Recessive Leber's Hereditary Optic Neuropathy. J. Clin. Invest. 2021. [CrossRef] [PubMed]

26. Agip, A.-N.A.; Blaza, J.N.; Fedor, J.G.; Hirst, J. Mammalian Respiratory Complex I Through the Lens of Cryo-EM. Annu. Rev. Biophys. 2019, 48, 165-184. [CrossRef]

27. Fiedorczuk, K.; Sazanov, L.A. Mammalian Mitochondrial Complex I Structure and Disease-Causing Mutations. Trends Cell Biol. 2018, 28, 835-867. [CrossRef]

28. Majander, A. Electron Transfer Properties of NADH: Ubiquinone Reductase in the ND1/3460 and the ND4/11778 Mutations of the Leber Hereditary Optic Neuroretinopathy (LHON). FEBS Lett. 1991, 292, 289-292. [CrossRef] 
29. Carelli, V.; Ghelli, A.; Ratta, M.; Bacchilega, E.; Sangiorgi, S.; Mancini, R.; Leuzzi, V.; Cortelli, P.; Montagna, P.; Lugaresi, E.; et al. Leber's Hereditary Optic Neuropathy: Biochemical Effect of 11778/ND4 and 3460/ND1 Mutations and Correlation with the Mitochondrial Genotype. Neurology 1997, 48, 1623-1632. [CrossRef]

30. Grba, D.N.; Hirst, J. Mitochondrial Complex I Structure Reveals Ordered Water Molecules for Catalysis and Proton Translocation. Nat. Struct. Mol. Biol. 2020, 27, 892-900. [CrossRef]

31. Larsson, N.-G.; Andersen, O.; Holme, E.; Oldfors, A.; Wahlström, J. Leber's Hereditary Optic Neuropathy and Complex I Deficiency in Muscle. Ann. Neurol. 1991, 30, 701-708. [CrossRef]

32. Degli-Esposti, M.; Carelli, V.; Ghelli, A.; Ratta, M.; Crimi, M.; Sangiorgi, S.; Montagna, P.; Lenaz, G.; Lugaresi, E.; Cortelli, P. Functional Alterations of the Mitochondrially Encoded ND4 Subunit Associated with Leber's Hereditary Optic Neuropathy. FEBS Lett. 1994, 352, 375-379. [CrossRef]

33. Carelli, V.; Ghelli, A.; Bucchi, L.; Montagna, P.; De Negri, A.; Leuzzi, V.; Carducci, C.; Lenaz, G.; Lugaresi, E.; Degli Esposti, M. Biochemical Features of MtDNA 14484 (ND6/M64V) Point Mutation Associated with Leber's Hereditary Optic Neuropathy. Ann. Neurol. 1999, 45, 320-328. [CrossRef]

34. Brown, M.D.; Trounce, I.A.; Jun, A.S.; Allen, J.C.; Wallace, D.C. Functional Analysis of Lymphoblast and Cybrid Mitochondria Containing the 3460, 11778, or 14484 Leber's Hereditary Optic Neuropathy Mitochondrial DNA Mutation. J. Biol. Chem. 2000, 275, 39831-39836. [CrossRef]

35. Brown, M.D. The Enigmatic Relationship between Mitochondrial Dysfunction and Leber's Hereditary Optic Neuropathy. J. Neurol. Sci. 1999, 165, 1-5. [CrossRef]

36. Baracca, A.; Solaini, G.; Sgarbi, G.; Lenaz, G.; Baruzzi, A.; Schapira, A.H.V.; Martinuzzi, A.; Carelli, V. Severe Impairment of Complex I-Driven Adenosine Triphosphate Synthesis in Leber Hereditary Optic Neuropathy Cybrids. Arch. Neurol. 2005, 62, 730. [CrossRef] [PubMed]

37. Kampjut, D.; Sazanov, L.A. The Coupling Mechanism of Mammalian Respiratory Complex I. Science 2020, 370. [CrossRef] [PubMed]

38. Danielson, S.R. Cells Bearing Mutations Causing Leber's Hereditary Optic Neuropathy Are Sensitized to Fas-Induced Apoptosis. J. Biol. Chem. 2002, 277, 5810-5815. [CrossRef]

39. Ghelli, A.; Zanna, C.; Porcelli, A.M.; Schapira, A.H.V.; Martinuzzi, A.; Carelli, V.; Rugolo, M. Leber's Hereditary Optic Neuropathy (LHON) Pathogenic Mutations Induce Mitochondrial-Dependent Apoptotic Death in Transmitochondrial Cells Incubated with Galactose Medium. J. Biol. Chem. 2003, 278, 4145-4150. [CrossRef] [PubMed]

40. Zanna, C.; Ghelli, A.; Porcelli, A.M.; Martinuzzi, A.; Carelli, V.; Rugolo, M. Caspase-Independent Death of Leber's Hereditary Optic Neuropathy Cybrids Is Driven by Energetic Failure and Mediated by AIF and Endonuclease G. Apoptosis 2005, 10, 997-1007. [CrossRef]

41. Caporali, L.; Maresca, A.; Capristo, M.; del Dotto, V.; Tagliavini, F.; Valentino, M.L.; la Morgia, C.; Carelli, V. Incomplete Penetrance in Mitochondrial Optic Neuropathies. Mitochondrion 2017, 36, 130-137. [CrossRef]

42. Torroni, A.; Petrozzi, M.; D’Urbano, L.; Sellitto, D.; Zeviani, M.; Carrara, F.; Carducci, C.; Leuzzi, V.; Carelli, V.; Barboni, P.; et al. Haplotype and Phylogenetic Analyses Suggest That One European-Specific MtDNA Background Plays a Role in the Expression of Leber Hereditary Optic Neuropathy by Increasing the Penetrance of the Primary Mutations 11778 and 14484 . Am. J. Hum. Genet. 1997, 60, 1107-1121. [PubMed]

43. Carelli, V.; Achilli, A.; Valentino, M.L.; Rengo, C.; Semino, O.; Pala, M.; Olivieri, A.; Mattiazzi, M.; Pallotti, F.; Carrara, F.; et al. Haplogroup Effects and Recombination of Mitochondrial DNA: Novel Clues from the Analysis of Leber Hereditary Optic Neuropathy Pedigrees. Am. J. Hum. Genet. 2006, 78, 564-574. [CrossRef] [PubMed]

44. Hudson, G.; Amati-Bonneau, P.; Blakely, E.L.; Stewart, J.D.; He, L.; Schaefer, A.M.; Griffiths, P.G.; Ahlqvist, K.; Suomalainen, A.; Reynier, P.; et al. Mutation of OPA1 Causes Dominant Optic Atrophy with External Ophthalmoplegia, Ataxia, Deafness and Multiple Mitochondrial DNA Deletions: A Novel Disorder of MtDNA Maintenance. Brain 2008, 131, 329-337. [CrossRef] [PubMed]

45. Pello, R.; Martín, M.A.; Carelli, V.; Nijtmans, L.G.; Achilli, A.; Pala, M.; Torroni, A.; Gómez-Durán, A.; Ruiz-Pesini, E.; Martinuzzi, A.; et al. Mitochondrial DNA Background Modulates the Assembly Kinetics of OXPHOS Complexes in a Cellular Model of Mitochondrial Disease. Hum. Mol. Genet. 2008, 17, 4001-4011. [CrossRef]

46. Ghelli, A.; Porcelli, A.M.; Zanna, C.; Vidoni, S.; Mattioli, S.; Barbieri, A.; Iommarini, L.; Pala, M.; Achilli, A.; Torroni, A.; et al. The Background of Mitochondrial DNA Haplogroup J Increases the Sensitivity of Leber's Hereditary Optic Neuropathy Cells to 2,5-Hexanedione Toxicity. PLoS ONE 2009, 4, e7922. [CrossRef]

47. Carelli, V.; Franceschini, F.; Venturi, S.; Barboni, P.; Savini, G.; Barbieri, G.; Pirro, E.; la Morgia, C.; Valentino, M.L.; Zanardi, F.; et al. Grand Rounds: Could Occupational Exposure to n-Hexane and Other Solvents Precipitate Visual Failure in Leber Hereditary Optic Neuropathy? Environ. Health Perspect. 2007, 115, 113-115. [CrossRef]

48. Strobbe, D.; Caporali, L.; Iommarini, L.; Maresca, A.; Montopoli, M.; Martinuzzi, A.; Achilli, A.; Olivieri, A.; Torroni, A.; Carelli, V.; et al. Haplogroup J Mitogenomes Are the Most Sensitive to the Pesticide Rotenone: Relevance for Human Diseases. Neurobiol. Dis. 2018, 114, 129-139. [CrossRef]

49. Giordano, C.; Montopoli, M.; Perli, E.; Orlandi, M.; Fantin, M.; Ross-Cisneros, F.N.; Caparrotta, L.; Martinuzzi, A.; Ragazzi, E.; Ghelli, A.; et al. Oestrogens Ameliorate Mitochondrial Dysfunction in Leber's Hereditary Optic Neuropathy. Brain 2011, 134, 220-234. [CrossRef] [PubMed] 
50. Giordano, C.; Iommarini, L.; Giordano, L.; Maresca, A.; Pisano, A.; Valentino, M.L.; Caporali, L.; Liguori, R.; Deceglie, S.; Roberti, M.; et al. Efficient Mitochondrial Biogenesis Drives Incomplete Penetrance in Leber's Hereditary Optic Neuropathy. Brain 2014, 137, 335-353. [CrossRef]

51. Kirkman, M.A.; Yu-Wai-Man, P.; Korsten, A.; Leonhardt, M.; Dimitriadis, K.; de Coo, I.F.; Klopstock, T.; Chinnery, P.F. GeneEnvironment Interactions in Leber Hereditary Optic Neuropathy. Brain 2009, 132, 2317-2326. [CrossRef]

52. Carelli, V.; d'Adamo, P.; Valentino, M.L.; la Morgia, C.; Ross-Cisneros, F.N.; Caporali, L.; Maresca, A.; Loguercio-Polosa, P.; Barboni, P.; de Negri, A.; et al. Parsing the Differences in Affected with LHON: Genetic versus Environmental Triggers of Disease Conversion. Brain 2016, 139, e17. [CrossRef] [PubMed]

53. Giordano, L.; Deceglie, S.; d'Adamo, P.; Valentino, M.L.; la Morgia, C.; Fracasso, F.; Roberti, M.; Cappellari, M.; Petrosillo, G.; Ciaravolo, S.; et al. Cigarette Toxicity Triggers Leber's Hereditary Optic Neuropathy by Affecting MtDNA Copy Number, Oxidative Phosphorylation and ROS Detoxification Pathways. Cell Death Dis. 2015, 6, e2021. [CrossRef] [PubMed]

54. Hanein, S.; Perrault, I.; Roche, O.; Gerber, S.; Khadom, N.; Rio, M.; Boddaert, N.; Jean-Pierre, M.; Brahimi, N.; Serre, V.; et al. TMEM126A, Encoding a Mitochondrial Protein, Is Mutated in Autosomal-Recessive Nonsyndromic Optic Atrophy. Am. J. Hum. Genet. 2009, 84, 493-498. [CrossRef]

55. D'Angelo, L.; Astro, E.; Luise, M.D.; Kurelac, I.; Umesh-Ganesh, N.; Ding, S.; Fearnley, I.M.; Zeviani, M.; Gasparre, G.; Porcelli, A.M.; et al. Biogenesis of NDUFS3-Less Complex I Indicates TMEM126A/OPA7 as an Assembly Factor of the ND4-Module. bioRxiv 2020. [CrossRef]

56. Formosa, L.E.; Reljic, B.; Sharpe, A.J.; Muellner-Wong, L.; Stroud, D.A.; Ryan, M.T. Optic Atrophy-Associated TMEM126A Is an Assembly Factor for the ND4-Module of Mitochondrial Complex I. bioRxiv 2020. [CrossRef]

57. Angebault, C.; Guichet, P.-O.; Talmat-Amar, Y.; Charif, M.; Gerber, S.; Fares-Taie, L.; Gueguen, N.; Halloy, F.; Moore, D.; AmatiBonneau, P.; et al. Recessive Mutations in RTN4IP1 Cause Isolated and Syndromic Optic Neuropathies. Am. J. Hum. Genet. 2015, 97, 754-760. [CrossRef] [PubMed]

58. Charif, M.; Nasca, A.; Thompson, K.; Gerber, S.; Makowski, C.; Mazaheri, N.; Bris, C.; Goudenège, D.; Legati, A.; Maroofian, R.; et al. Neurologic Phenotypes Associated With Mutations in RTN4IP1 (OPA10) in Children and Young Adults. JAMA Neurol. 2018, 75, 105-113. [CrossRef]

59. Tilokani, L.; Nagashima, S.; Paupe, V.; Prudent, J. Mitochondrial Dynamics: Overview of Molecular Mechanisms. Essays Biochem. 2018, 62, 341-360. [CrossRef]

60. Giacomello, M.; Pyakurel, A.; Glytsou, C.; Scorrano, L. The Cell Biology of Mitochondrial Membrane Dynamics. Nat. Rev. Mol. Cell Biol. 2020, 21, 204-224. [CrossRef]

61. Del Dotto, V.; Fogazza, M.; Carelli, V.; Rugolo, M.; Zanna, C. Eight Human OPA1 Isoforms, Long and Short: What Are They For? Biochim. Biophys. Acta Bioenerg. 2018, 1859, 263-269. [CrossRef]

62. Griparic, L.; Kanazawa, T.; van der Bliek, A.M. Regulation of the Mitochondrial Dynamin-like Protein Opa1 by Proteolytic Cleavage. J. Cell Biol. 2007, 178, 757-764. [CrossRef]

63. Ehses, S.; Raschke, I.; Mancuso, G.; Bernacchia, A.; Geimer, S.; Tondera, D.; Martinou, J.-C.; Westermann, B.; Rugarli, E.I.; Langer, T. Regulation of OPA1 Processing and Mitochondrial Fusion by M-AAA Protease Isoenzymes and OMA1. J. Cell Biol. 2009, 187, 1023-1036. [CrossRef] [PubMed]

64. Anand, R.; Wai, T.; Baker, M.J.; Kladt, N.; Schauss, A.C.; Rugarli, E.; Langer, T. The I-AAA Protease YME1L and OMA1 Cleave OPA1 to Balance Mitochondrial Fusion and Fission. J. Cell Biol. 2014, 204, 919-929. [CrossRef] [PubMed]

65. Song, Z.; Chen, H.; Fiket, M.; Alexander, C.; Chan, D.C. OPA1 Processing Controls Mitochondrial Fusion and Is Regulated by MRNA Splicing, Membrane Potential, and Yme1L. J. Cell Biol. 2007, 178, 749-755. [CrossRef] [PubMed]

66. Dotto, V.D.; Mishra, P.; Vidoni, S.; Fogazza, M.; Maresca, A.; Caporali, L.; McCaffery, J.M.; Cappelletti, M.; Baruffini, E.; Lenaers, G.; et al. OPA1 Isoforms in the Hierarchical Organization of Mitochondrial Functions. Cell Rep. 2017, 19, 2557-2571. [CrossRef]

67. Ban, T.; Ishihara, T.; Kohno, H.; Saita, S.; Ichimura, A.; Maenaka, K.; Oka, T.; Mihara, K.; Ishihara, N. Molecular Basis of Selective Mitochondrial Fusion by Heterotypic Action between OPA1 and Cardiolipin. Nat. Cell Biol. 2017, 19, 856-863. [CrossRef]

68. Wang, R.; Mishra, P.; Garbis, S.D.; Moradian, A.; Sweredoski, M.J.; Chan, D.C. Identification of New OPA1 Cleavage Site Reveals That Short Isoforms Regulate Mitochondrial Fusion. Mol. Biol. Cell 2021, 32, 157-168. [CrossRef]

69. MacVicar, T.; Langer, T. OPA1 Processing in Cell Death and Disease-The Long and Short of It. J Cell Sci 2016, 129, 2297-2306. [CrossRef]

70. Baker, M.J.; Lampe, P.A.; Stojanovski, D.; Korwitz, A.; Anand, R.; Tatsuta, T.; Langer, T. Stress-Induced OMA1 Activation and Autocatalytic Turnover Regulate OPA1-Dependent Mitochondrial Dynamics. EMBO J. 2014, 33, 578-593. [CrossRef]

71. Zhang, K.; Li, H.; Song, Z. Membrane Depolarization Activates the Mitochondrial Protease OMA1 by Stimulating Self-Cleavage. EMBO Rep. 2014, 15, 576-585. [CrossRef]

72. Rainbolt, T.K.; Saunders, J.M.; Wiseman, R.L. YME1L Degradation Reduces Mitochondrial Proteolytic Capacity during Oxidative Stress. EMBO Rep. 2015, 16, 97-106. [CrossRef] [PubMed]

73. Consolato, F.; Maltecca, F.; Tulli, S.; Sambri, I.; Casari, G. M-AAA and i-AAA Complexes Coordinate to Regulate OMA1, the Stress-Activated Supervisor of Mitochondrial Dynamics. J. Cell Sci. 2018, 131. [CrossRef] [PubMed]

74. Richter, U.; Ng, K.Y.; Suomi, F.; Marttinen, P.; Turunen, T.; Jackson, C.; Suomalainen, A.; Vihinen, H.; Jokitalo, E.; Nyman, T.A.; et al. Mitochondrial Stress Response Triggered by Defects in Protein Synthesis Quality Control. Life Sci. Alliance 2019, 2. [CrossRef] [PubMed] 
75. Tulli, S.; Bondio, A.D.; Baderna, V.; Mazza, D.; Codazzi, F.; Pierson, T.M.; Ambrosi, A.; Nolte, D.; Goizet, C.; Toro, C.; et al. Pathogenic Variants in the AFG3L2 Proteolytic Domain Cause SCA28 through Haploinsufficiency and Proteostatic Stress-Driven OMA1 Activation. J. Med. Genet. 2019, 56, 499-511. [CrossRef]

76. Tondera, D.; Grandemange, S.; Jourdain, A.; Karbowski, M.; Mattenberger, Y.; Herzig, S.; Da Cruz, S.; Clerc, P.; Raschke, I.; Merkwirth, C.; et al. SLP-2 Is Required for Stress-Induced Mitochondrial Hyperfusion. EMBO J. 2009, 28, 1589-1600. [CrossRef]

77. Wai, T.; Saita, S.; Nolte, H.; Müller, S.; König, T.; Richter-Dennerlein, R.; Sprenger, H.-G.; Madrenas, J.; Mühlmeister, M.; Brandt, U.; et al. The Membrane Scaffold SLP2 Anchors a Proteolytic Hub in Mitochondria Containing PARL and the I-AAA Protease YME1L. EMBO Rep. 2016, 17, 1844-1856. [CrossRef]

78. Olichon, A.; ElAchouri, G.; Baricault, L.; Delettre, C.; Belenguer, P.; Lenaers, G. OPA1 Alternate Splicing Uncouples an Evolutionary Conserved Function in Mitochondrial Fusion from a Vertebrate Restricted Function in Apoptosis. Cell Death Differ. 2007, 14, 682-692. [CrossRef]

79. Lee, H.; Smith, S.B.; Yoon, Y. The Short Variant of the Mitochondrial Dynamin OPA1 Maintains Mitochondrial Energetics and Cristae Structure. J. Biol. Chem. 2017, 292, 7115-7130. [CrossRef]

80. Del Dotto, V.; Fogazza, M.; Musiani, F.; Maresca, A.; Aleo, S.J.; Caporali, L.; la Morgia, C.; Nolli, C.; Lodi, T.; Goffrini, P.; et al. Deciphering OPA1 Mutations Pathogenicity by Combined Analysis of Human, Mouse and Yeast Cell Models. Biochim. Biophys. Acta Mol. Basis Dis. 2018, 1864, 3496-3514. [CrossRef] [PubMed]

81. Zanna, C.; Ghelli, A.; Porcelli, A.M.; Karbowski, M.; Youle, R.J.; Schimpf, S.; Wissinger, B.; Pinti, M.; Cossarizza, A.; Vidoni, S.; et al. OPA1 Mutations Associated with Dominant Optic Atrophy Impair Oxidative Phosphorylation and Mitochondrial Fusion. Brain 2008, 131, 352-367. [CrossRef] [PubMed]

82. Chevrollier, A.; Guillet, V.; Loiseau, D.; Gueguen, N.; de Crescenzo, M.-A.P.; Verny, C.; Ferre, M.; Dollfus, H.; Odent, S.; Milea, D.; et al. Hereditary Optic Neuropathies Share a Common Mitochondrial Coupling Defect. Ann. Neurol. 2008, 63, 794-798. [CrossRef]

83. Agier, V.; Oliviero, P.; Lainé, J.; L’Hermitte-Stead, C.; Girard, S.; Fillaut, S.; Jardel, C.; Bouillaud, F.; Bulteau, A.L.; Lombès, A. Defective Mitochondrial Fusion, Altered Respiratory Function, and Distorted Cristae Structure in Skin Fibroblasts with Heterozygous OPA1 Mutations. Biochim. Biophys. Acta Mol. Basis Dis. 2012, 1822, 1570-1580. [CrossRef]

84. Alavi, M.V.; Bette, S.; Schimpf, S.; Schuettauf, F.; Schraermeyer, U.; Wehrl, H.F.; Ruttiger, L.; Beck, S.C.; Tonagel, F.; Pichler, B.J.; et al. A Splice Site Mutation in the Murine Opa1 Gene Features Pathology of Autosomal Dominant Optic Atrophy. Brain 2007, 130, 1029-1042. [CrossRef]

85. Davies, V.J.; Hollins, A.J.; Piechota, M.J.; Yip, W.; Davies, J.R.; White, K.E.; Nicols, P.P.; Boulton, M.E.; Votruba, M. Opa1 Deficiency in a Mouse Model of Autosomal Dominant Optic Atrophy Impairs Mitochondrial Morphology, Optic Nerve Structure and Visual Function. Hum. Mol. Genet. 2007, 16, 1307-1318. [CrossRef]

86. Sarzi, E.; Angebault, C.; Seveno, M.; Gueguen, N.; Chaix, B.; Bielicki, G.; Boddaert, N.; Mausset-Bonnefont, A.-L.; Cazevieille, C.; Rigau, V.; et al. The Human OPA1delTTAG Mutation Induces Premature Age-Related Systemic Neurodegeneration in Mouse. Brain 2012, 135, 3599-3613. [CrossRef] [PubMed]

87. Williams, P.A.; Morgan, J.E.; Votruba, M. Mouse Models of Dominant Optic Atrophy: What Do They Tell Us about the Pathophysiology of Visual Loss? Vis. Res. 2011, 51, 229-234. [CrossRef] [PubMed]

88. Carelli, V.; Musumeci, O.; Caporali, L.; Zanna, C.; Morgia, C.L.; Dotto, V.D.; Porcelli, A.M.; Rugolo, M.; Valentino, M.L.; Iommarini, L.; et al. Syndromic Parkinsonism and Dementia Associated with OPA1 Missense Mutations. Ann. Neurol. 2015, 78, 21-38. [CrossRef] [PubMed]

89. Yu-Wai-Man, P.; Sitarz, K.S.; Samuels, D.C.; Griffiths, P.G.; Reeve, A.K.; Bindoff, L.A.; Horvath, R.; Chinnery, P.F. OPA1 Mutations Cause Cytochrome c Oxidase Deficiency Due to Loss of Wild-Type MtDNA Molecules. Hum Mol. Genet. 2010, 19, $3043-3052$. [CrossRef] [PubMed]

90. Iannielli, A.; Bido, S.; Folladori, L.; Segnali, A.; Cancellieri, C.; Maresca, A.; Massimino, L.; Rubio, A.; Morabito, G.; Caporali, L.; et al. Pharmacological Inhibition of Necroptosis Protects from Dopaminergic Neuronal Cell Death in Parkinson's Disease Models. Cell Rep. 2018, 22, 2066-2079. [CrossRef]

91. Jonikas, M.; Madill, M.; Mathy, A.; Zekoll, T.; Zois, C.E.; Wigfield, S.; Kurzawa-Akanbi, M.; Browne, C.; Sims, D.; Chinnery, P.F.; et al. Stem Cell Modeling of Mitochondrial Parkinsonism Reveals Key Functions of OPA1. Ann. Neurol. 2018, 83, 915-925. [CrossRef]

92. Iannielli, A.; Ugolini, G.S.; Cordiglieri, C.; Bido, S.; Rubio, A.; Colasante, G.; Valtorta, M.; Cabassi, T.; Rasponi, M.; Broccoli, V. Reconstitution of the Human Nigro-Striatal Pathway on-a-Chip Reveals OPA1-Dependent Mitochondrial Defects and Loss of Dopaminergic Synapses. Cell Rep. 2019, 29, 4646-4656.e4. [CrossRef]

93. Kane, M.S.; Alban, J.; Desquiret-Dumas, V.; Gueguen, N.; Ishak, L.; Ferre, M.; Amati-Bonneau, P.; Procaccio, V.; Bonneau, D.; Lenaers, G.; et al. Autophagy Controls the Pathogenicity of OPA1 Mutations in Dominant Optic Atrophy. J. Cell. Mol. Med. 2017, 21, 2284-2297. [CrossRef] [PubMed]

94. Liao, C.; Ashley, N.; Diot, A.; Morten, K.; Phadwal, K.; Williams, A.; Fearnley, I.; Rosser, L.; Lowndes, J.; Fratter, C.; et al. Dysregulated Mitophagy and Mitochondrial Organization in Optic Atrophy Due to OPA1 Mutations. Neurology 2017, 88, 131-142. [CrossRef] [PubMed]

95. White, K.E.; Davies, V.J.; Hogan, V.E.; Piechota, M.J.; Nichols, P.P.; Turnbull, D.M.; Votruba, M. OPA1 Deficiency Associated with Increased Autophagy in Retinal Ganglion Cells in a Murine Model of Dominant Optic Atrophy. Invest. Ophthalmol. Vis. Sci. 2009, 50, 2567-2571. [CrossRef] 
96. Diot, A.; Agnew, T.; Sanderson, J.; Liao, C.; Carver, J.; das Neves, R.P.; Gupta, R.; Guo, Y.; Waters, C.; Seto, S.; et al. Validating the RedMIT/GFP-LC3 Mouse Model by Studying Mitophagy in Autosomal Dominant Optic Atrophy Due to the OPA1Q285STOP Mutation. Front. Cell Dev. Biol. 2018, 6, 103. [CrossRef]

97. Zaninello, M.; Palikaras, K.; Naon, D.; Iwata, K.; Herkenne, S.; Quintana-Cabrera, R.; Semenzato, M.; Grespi, F.; Ross-Cisneros, F.N.; Carelli, V.; et al. Inhibition of Autophagy Curtails Visual Loss in a Model of Autosomal Dominant Optic Atrophy. Nat. Commun. 2020, 11, 4029. [CrossRef]

98. Bocca, C.; Nzoughet, J.K.; Leruez, S.; Amati-Bonneau, P.; Ferré, M.; Kane, M.-S.; Veyrat-Durebex, C.; de la Barca, J.M.C.; Chevrollier, A.; Homedan, C.; et al. A Plasma Metabolomic Signature Involving Purine Metabolism in Human Optic Atrophy 1 (OPA1)-Related Disorders. Invest. Ophthalmol. Vis. Sci. 2018, 59, 185-195. [CrossRef]

99. Bocca, C.; Kane, M.S.; Veyrat-Durebex, C.; Nzoughet, J.K.; Chao de la Barca, J.M.; Chupin, S.; Alban, J.; Procaccio, V.; Bonneau, D.; Simard, G.; et al. Lipidomics Reveals Triacylglycerol Accumulation Due to Impaired Fatty Acid Flux in Opa1-Disrupted Fibroblasts. J. Proteome Res. 2019, 18, 2779-2790. [CrossRef] [PubMed]

100. Chao de la Barca, J.M.; Fogazza, M.; Rugolo, M.; Chupin, S.; del Dotto, V.; Ghelli, A.M.; Carelli, V.; Simard, G.; Procaccio, V.; Bonneau, D.; et al. Metabolomics Hallmarks OPA1 Variants Correlating with Their in Vitro Phenotype and Predicting Clinical Severity. Hum. Mol. Genet. 2020, 29, 1319-1329. [CrossRef]

101. Chao de la Barca, J.M.; Simard, G.; Sarzi, E.; Chaumette, T.; Rousseau, G.; Chupin, S.; Gadras, C.; Tessier, L.; Ferré, M.; Chevrollier, A.; et al. Targeted Metabolomics Reveals Early Dominant Optic Atrophy Signature in Optic Nerves of Opa1delTTAG/+ Mice. Invest. Ophthalmol. Vis. Sci. 2017, 58, 812-820. [CrossRef]

102. Buzkova, J.; Nikkanen, J.; Ahola, S.; Hakonen, A.H.; Sevastianova, K.; Hovinen, T.; Yki-Järvinen, H.; Pietiläinen, K.H.; Lönnqvist, T.; Velagapudi, V.; et al. Metabolomes of Mitochondrial Diseases and Inclusion Body Myositis Patients: Treatment Targets and Biomarkers. EMBO Mol. Med. 2018, 10, e9091. [CrossRef]

103. Chen, Q.; Kirk, K.; Shurubor, Y.I.; Zhao, D.; Arreguin, A.J.; Shahi, I.; Valsecchi, F.; Primiano, G.; Calder, E.L.; Carelli, V.; et al. Rewiring of Glutamine Metabolism Is a Bioenergetic Adaptation of Human Cells with Mitochondrial DNA Mutations. Cell Metab. 2018, 27, 1007-1025.e5. [CrossRef]

104. Nikkanen, J.; Forsström, S.; Euro, L.; Paetau, I.; Kohnz, R.A.; Wang, L.; Chilov, D.; Viinamäki, J.; Roivainen, A.; Marjamäki, P.; et al. Mitochondrial DNA Replication Defects Disturb Cellular DNTP Pools and Remodel One-Carbon Metabolism. Cell Metab. 2016, 23, 635-648. [CrossRef] [PubMed]

105. Maresca, A.; del Dotto, V.; Capristo, M.; Scimonelli, E.; Tagliavini, F.; Morandi, L.; Tropeano, C.V.; Caporali, L.; Mohamed, S.; Roberti, M.; et al. DNMT1 Mutations Leading to Neurodegeneration Paradoxically Reflect on Mitochondrial Metabolism. Hum. Mol. Genet. 2020, 29, 1864-1881. [CrossRef] [PubMed]

106. Di Bella, D.; Lazzaro, F.; Brusco, A.; Plumari, M.; Battaglia, G.; Pastore, A.; Finardi, A.; Cagnoli, C.; Tempia, F.; Frontali, M.; et al. Mutations in the Mitochondrial Protease Gene AFG3L2 Cause Dominant Hereditary Ataxia SCA28. Nat. Genet. 2010, 42, 313-321. [CrossRef] [PubMed]

107. Pierson, T.M.; Adams, D.; Bonn, F.; Martinelli, P.; Cherukuri, P.F.; Teer, J.K.; Hansen, N.F.; Cruz, P.; Program, J.C.M. for the N.C.S.; Blakesley, R.W.; et al. Whole-Exome Sequencing Identifies Homozygous AFG3L2 Mutations in a Spastic Ataxia-Neuropathy Syndrome Linked to Mitochondrial m-AAA Proteases. PLoS Genet. 2011, 7, e1002325. [CrossRef]

108. Casari, G.; de Fusco, M.; Ciarmatori, S.; Zeviani, M.; Mora, M.; Fernandez, P.; de Michele, G.; Filla, A.; Cocozza, S.; Marconi, R.; et al. Spastic Paraplegia and OXPHOS Impairment Caused by Mutations in Paraplegin, a Nuclear-Encoded Mitochondrial Metalloprotease. Cell 1998, 93, 973-983. [CrossRef]

109. Caporali, L.; Magri, S.; Legati, A.; Dotto, V.D.; Tagliavini, F.; Balistreri, F.; Nasca, A.; Morgia, C.L.; Carbonelli, M.; Valentino, M.L.; et al. ATPase Domain AFG3L2 Mutations Alter OPA1 Processing and Cause Optic Neuropathy. Ann. Neurol. 2020, 88, 18-32. [CrossRef]

110. Charif, M.; Chevrollier, A.; Gueguen, N.; Bris, C.; Goudenège, D.; Desquiret-Dumas, V.; Leruez, S.; Colin, E.; Meunier, A.; Vignal, C.; et al. Mutations in the M-AAA Proteases AFG3L2 and SPG7 Are Causing Isolated Dominant Optic Atrophy. Neurol. Genet. 2020, 6. [CrossRef]

111. Baderna, V.; Schultz, J.; Kearns, L.S.; Fahey, M.; Thompson, B.A.; Ruddle, J.B.; Huq, A.; Maltecca, F. A Novel AFG3L2 Mutation Close to AAA Domain Leads to Aberrant OMA1 and OPA1 Processing in a Family with Optic Atrophy I Acta Neuropathologica Communications I Full Text. Available online: https://actaneurocomms.biomedcentral.com/articles/10.1186/s40478-020-00975 -w (accessed on 16 February 2021).

112. Magri, S.; Fracasso, V.; Plumari, M.; Alfei, E.; Ghezzi, D.; Gellera, C.; Rusmini, P.; Poletti, A.; Bella, D.D.; Elia, A.E.; et al. Concurrent AFG3L2 and SPG7 Mutations Associated with Syndromic Parkinsonism and Optic Atrophy with Aberrant OPA1 Processing and Mitochondrial Network Fragmentation. Hum. Mutat. 2018, 39, 2060-2071. [CrossRef]

113. Klebe, S.; Depienne, C.; Gerber, S.; Challe, G.; Anheim, M.; Charles, P.; Fedirko, E.; Lejeune, E.; Cottineau, J.; Brusco, A.; et al. Spastic Paraplegia Gene 7 in Patients with Spasticity and/or Optic Neuropathy. Brain 2012, 135, 2980-2993. [CrossRef]

114. Pfeffer, G.; Gorman, G.S.; Griffin, H.; Kurzawa-Akanbi, M.; Blakely, E.L.; Wilson, I.; Sitarz, K.; Moore, D.; Murphy, J.L.; Alston, C.L.; et al. Mutations in the SPG7 Gene Cause Chronic Progressive External Ophthalmoplegia through Disordered Mitochondrial DNA Maintenance. Brain 2014, 137, 1323-1336. [CrossRef] 
115. Hartmann, B.; Wai, T.; Hu, H.; MacVicar, T.; Musante, L.; Fischer-Zirnsak, B.; Stenzel, W.; Gräf, R.; van den Heuvel, L.; Ropers, H.-H.; et al. Homozygous YME1L1 Mutation Causes Mitochondriopathy with Optic Atrophy and Mitochondrial Network Fragmentation. eLife 2016, 5, e16078. [CrossRef]

116. Sprenger, H.-G.; Wani, G.; Hesseling, A.; König, T.; Patron, M.; MacVicar, T.; Ahola, S.; Wai, T.; Barth, E.; Rugarli, E.I.; et al. Loss of the Mitochondrial I-AAA Protease YME1L Leads to Ocular Dysfunction and Spinal Axonopathy. EMBO Mol. Med. 2019, 11, e9288. [CrossRef]

117. Wai, T.; García-Prieto, J.; Baker, M.J.; Merkwirth, C.; Benit, P.; Rustin, P.; Rupérez, F.J.; Barbas, C.; Ibañez, B.; Langer, T. Imbalanced OPA1 Processing and Mitochondrial Fragmentation Cause Heart Failure in Mice. Science 2015, 350. [CrossRef] [PubMed]

118. MacVicar, T.; Ohba, Y.; Nolte, H.; Mayer, F.C.; Tatsuta, T.; Sprenger, H.-G.; Lindner, B.; Zhao, Y.; Li, J.; Bruns, C.; et al. Lipid Signalling Drives Proteolytic Rewiring of Mitochondria by YME1L. Nature 2019, 575, 361-365. [CrossRef] [PubMed]

119. Chen, H.; Detmer, S.A.; Ewald, A.J.; Griffin, E.E.; Fraser, S.E.; Chan, D.C. Mitofusins Mfn1 and Mfn2 Coordinately Regulate Mitochondrial Fusion and Are Essential for Embryonic Development. J. Cell Biol. 2003, 160, 189-200. [CrossRef] [PubMed]

120. Eura, Y.; Ishihara, N.; Yokota, S.; Mihara, K. Two Mitofusin Proteins, Mammalian Homologues of FZO, with Distinct Functions Are Both Required for Mitochondrial Fusion. J. Biochem. 2003, 134, 333-344. [CrossRef]

121. Ishihara, N.; Eura, Y.; Mihara, K. Mitofusin 1 and 2 Play Distinct Roles in Mitochondrial Fusion Reactions via GTPase Activity. J. Cell Sci. 2004, 117, 6535-6546. [CrossRef] [PubMed]

122. de Brito, O.M.; Scorrano, L. Mitofusin 2 Tethers Endoplasmic Reticulum to Mitochondria. Nature 2008, 456, 605-610. [CrossRef] [PubMed]

123. Naon, D.; Zaninello, M.; Giacomello, M.; Varanita, T.; Grespi, F.; Lakshminaranayan, S.; Serafini, A.; Semenzato, M.; Herkenne, S.; Hernández-Alvarez, M.I.; et al. Critical Reappraisal Confirms That Mitofusin 2 Is an Endoplasmic Reticulum-Mitochondria Tether. PNAS 2016, 113, 11249-11254. [CrossRef]

124. Filadi, R.; Greotti, E.; Turacchio, G.; Luini, A.; Pozzan, T.; Pizzo, P. Mitofusin 2 Ablation Increases Endoplasmic ReticulumMitochondria Coupling. PNAS 2015, 112, E2174-E2181. [CrossRef]

125. Giorgi, C.; Missiroli, S.; Patergnani, S.; Duszynski, J.; Wieckowski, M.R.; Pinton, P. Mitochondria-Associated Membranes: Composition, Molecular Mechanisms, and Physiopathological Implications. Antioxid. Redox Signal. 2015, 22, 995-1019. [CrossRef]

126. Züchner, S.; Mersiyanova, I.V.; Muglia, M.; Bissar-Tadmouri, N.; Rochelle, J.; Dadali, E.L.; Zappia, M.; Nelis, E.; Patitucci, A.; Senderek, J.; et al. Mutations in the Mitochondrial GTPase Mitofusin 2 Cause Charcot-Marie-Tooth Neuropathy Type 2A. Nat. Genet. 2004, 36, 449-451. [CrossRef] [PubMed]

127. Züchner, S.; de Jonghe, P.; Jordanova, A.; Claeys, K.G.; Guergueltcheva, V.; Cherninkova, S.; Hamilton, S.R.; van Stavern, G.; Krajewski, K.M.; Stajich, J.; et al. Axonal Neuropathy with Optic Atrophy Is Caused by Mutations in Mitofusin 2. Ann. Neurol. 2006, 59, 276-281. [CrossRef]

128. Rouzier, C.; Bannwarth, S.; Chaussenot, A.; Chevrollier, A.; Verschueren, A.; Bonello-Palot, N.; Fragaki, K.; Cano, A.; Pouget, J.; Pellissier, J.-F.; et al. The MFN2 Gene Is Responsible for Mitochondrial DNA Instability and Optic Atrophy "plus" Phenotype. Brain 2012, 135, 23-34. [CrossRef] [PubMed]

129. Guillet, V.; Gueguen, N.; Cartoni, R.; Chevrollier, A.; Desquiret, V.; Angebault, C.; Amati-Bonneau, P.; Procaccio, V.; Bonneau, D.; Martinou, J.-C.; et al. Bioenergetic Defect Associated with MKATP Channel Opening in a Mouse Model Carrying a Mitofusin 2 Mutation. FASEB J. 2011, 25, 1618-1627. [CrossRef]

130. Misko, A.L.; Sasaki, Y.; Tuck, E.; Milbrandt, J.; Baloh, R.H. Mitofusin2 Mutations Disrupt Axonal Mitochondrial Positioning and Promote Axon Degeneration. J. Neurosci. 2012, 32, 4145-4155. [CrossRef] [PubMed]

131. Baloh, R.H.; Schmidt, R.E.; Pestronk, A.; Milbrandt, J. Altered Axonal Mitochondrial Transport in the Pathogenesis of CharcotMarie-Tooth Disease from Mitofusin 2 Mutations. J. Neurosci. 2007, 27, 422-430. [CrossRef]

132. Wolf, C.; Zimmermann, R.; Thaher, O.; Bueno, D.; Wüllner, V.; Schäfer, M.K.E.; Albrecht, P.; Methner, A. The Charcot-Marie Tooth Disease Mutation R94Q in MFN2 Decreases ATP Production but Increases Mitochondrial Respiration under Conditions of Mild Oxidative Stress. Cells 2019, 8, 1289. [CrossRef]

133. Amiott, E.A.; Lott, P.; Soto, J.; Kang, P.B.; McCaffery, J.M.; DiMauro, S.; Abel, E.D.; Flanigan, K.M.; Lawson, V.H.; Shaw, J.M. Mitochondrial Fusion and Function in Charcot-Marie-Tooth Type 2A Patient Fibroblasts with Mitofusin 2 Mutations. Exp. Neurol. 2008, 211, 115-127. [CrossRef]

134. Codron, P.; Chevrollier, A.; Kane, M.S.; Echaniz-Laguna, A.; Latour, P.; Reynier, P.; Bonneau, D.; Verny, C.; Procaccio, V.; Lenaers, G.; et al. Increased Mitochondrial Fusion in a Autosomal Recessive CMT2A Family with Mitochondrial GTPase Mitofusin 2 Mutations. J. Peripher. Nerv. Syst. 2016, 21, 365-369. [CrossRef]

135. Vielhaber, S.; Debska-Vielhaber, G.; Peeva, V.; Schoeler, S.; Kudin, A.P.; Minin, I.; Schreiber, S.; Dengler, R.; Kollewe, K.; Zuschratter, W.; et al. Mitofusin 2 Mutations Affect Mitochondrial Function by Mitochondrial DNA Depletion. Acta Neuropathol. 2013, 125, 245-256. [CrossRef]

136. Rizzo, F.; Ronchi, D.; Salani, S.; Nizzardo, M.; Fortunato, F.; Bordoni, A.; Stuppia, G.; Del Bo, R.; Piga, D.; Fato, R.; et al. Selective Mitochondrial Depletion, Apoptosis Resistance, and Increased Mitophagy in Human Charcot-Marie-Tooth 2A Motor Neurons. Hum. Mol. Genet. 2016, 25, 4266-4281. [CrossRef]

137. Bernard-Marissal, N.; van Hameren, G.; Juneja, M.; Pellegrino, C.; Louhivuori, L.; Bartesaghi, L.; Rochat, C.; Mansour, O.E.; Médard, J.-J.; Croisier, M.; et al. Altered Interplay between Endoplasmic Reticulum and Mitochondria in Charcot-Marie-Tooth Type 2A Neuropathy. PNAS 2019, 116, 2328-2337. [CrossRef] [PubMed] 
138. Larrea, D.; Pera, M.; Gonnelli, A.; Quintana-Cabrera, R.; Akman, H.O.; Guardia-Laguarta, C.; Velasco, K.R.; Area-Gomez, E.; dal Bello, F.; de Stefani, D.; et al. MFN2 Mutations in Charcot-Marie-Tooth Disease Alter Mitochondria-Associated ER Membrane Function but Do Not Impair Bioenergetics. Hum. Mol. Genet. 2019, 28, 1782-1800. [CrossRef]

139. Nasca, A.; Scotton, C.; Zaharieva, I.; Neri, M.; Selvatici, R.; Magnusson, O.T.; Gal, A.; Weaver, D.; Rossi, R.; Armaroli, A.; et al. Recessive Mutations in MSTO1 Cause Mitochondrial Dynamics Impairment, Leading to Myopathy and Ataxia. Hum. Mutat. 2017, 38, 970-977. [CrossRef] [PubMed]

140. Gal, A.; Balicza, P.; Weaver, D.; Naghdi, S.; Joseph, S.K.; Várnai, P.; Gyuris, T.; Horváth, A.; Nagy, L.; Seifert, E.L.; et al. MSTO1 Is a Cytoplasmic Pro-Mitochondrial Fusion Protein, Whose Mutation Induces Myopathy and Ataxia in Humans. EMBO Mol. Med. 2017, 9, 967-984. [CrossRef] [PubMed]

141. Donkervoort, S.; Sabouny, R.; Yun, P.; Gauquelin, L.; Chao, K.R.; Hu, Y.; Al-Khatib, I.; Töpf, A.; Mohassel, P.; Cummings, B.B.; et al. MSTO1 Mutations Cause MtDNA Depletion, Manifesting as Muscular Dystrophy with Cerebellar Involvement. Acta Neuropathol. 2019, 138, 1013-1031. [CrossRef]

142. Li, K.; Jin, R.; Wu, X. Whole-Exome Sequencing Identifies Rare Compound Heterozygous Mutations in the MSTO1 Gene Associated with Cerebellar Ataxia and Myopathy. Eur. J. Med. Genet. 2020, 63, 103623. [CrossRef] [PubMed]

143. Fröhlich, C.; Grabiger, S.; Schwefel, D.; Faelber, K.; Rosenbaum, E.; Mears, J.; Rocks, O.; Daumke, O. Structural Insights into Oligomerization and Mitochondrial Remodelling of Dynamin 1-like Protein. EMBO J. 2013, 32, 1280-1292. [CrossRef]

144. Losón, O.C.; Song, Z.; Chen, H.; Chan, D.C. Fis1, Mff, MiD49, and MiD51 Mediate Drp1 Recruitment in Mitochondrial Fission. Mol. Biol. Cell 2013, 24, 659-667. [CrossRef]

145. Friedman, J.R.; Lackner, L.L.; West, M.; DiBenedetto, J.R.; Nunnari, J.; Voeltz, G.K. ER Tubules Mark Sites of Mitochondrial Division. Science 2011, 334, 358-362. [CrossRef]

146. Manor, U.; Bartholomew, S.; Golani, G.; Christenson, E.; Kozlov, M.; Higgs, H.; Spudich, J.; Lippincott-Schwartz, J. A MitochondriaAnchored Isoform of the Actin-Nucleating Spire Protein Regulates Mitochondrial Division. eLife 2015, 4, e08828. [CrossRef]

147. Mears, J.A.; Lackner, L.L.; Fang, S.; Ingerman, E.; Nunnari, J.; Hinshaw, J.E. Conformational Changes in Dnm1 Support a Contractile Mechanism for Mitochondrial Fission. Nat. Struct. Mol. Biol. 2011, 18, 20-26. [CrossRef]

148. Ban-Ishihara, R.; Ishihara, T.; Sasaki, N.; Mihara, K.; Ishihara, N. Dynamics of Nucleoid Structure Regulated by Mitochondrial Fission Contributes to Cristae Reformation and Release of Cytochrome c. PNAS 2013, 110, 11863-11868. [CrossRef] [PubMed]

149. Korobova, F.; Ramabhadran, V.; Higgs, H.N. An Actin-Dependent Step in Mitochondrial Fission Mediated by the ER-Associated Formin INF2. Science 2013, 339, 464-467. [CrossRef] [PubMed]

150. Li, S.; Xu, S.; Roelofs, B.A.; Boyman, L.; Lederer, W.J.; Sesaki, H.; Karbowski, M. Transient Assembly of F-Actin on the Outer Mitochondrial Membrane Contributes to Mitochondrial Fission. J. Cell Biol. 2014, 208, 109-123. [CrossRef] [PubMed]

151. Korobova, F.; Gauvin, T.J.; Higgs, H.N. A Role for Myosin II in Mammalian Mitochondrial Fission. Curr. Biol. 2014, $24,409-414$. [CrossRef]

152. Li, G.; Zhou, J.; Budhraja, A.; Hu, X.; Chen, Y.; Cheng, Q.; Liu, L.; Zhou, T.; Li, P.; Liu, E.; et al. Mitochondrial Translocation and Interaction of Cofilin and Drp1 Are Required for Erucin-Induced Mitochondrial Fission and Apoptosis. Oncotarget 2014, 6, 1834-1849. [CrossRef] [PubMed]

153. Rehklau, K.; Hoffmann, L.; Gurniak, C.B.; Ott, M.; Witke, W.; Scorrano, L.; Culmsee, C.; Rust, M.B. Cofilin1-Dependent Actin Dynamics Control DRP1-Mediated Mitochondrial Fission. Cell Death Dis. 2017, 8, e3063. [CrossRef]

154. Pagliuso, A.; Tham, T.N.; Stevens, J.K.; Lagache, T.; Persson, R.; Salles, A.; Olivo-Marin, J.-C.; Oddos, S.; Spang, A.; Cossart, P.; et al. A Role for Septin 2 in Drp1-Mediated Mitochondrial Fission. EMBO Rep. 2016, 17, 858-873. [CrossRef]

155. Yoon, Y.; Pitts, K.R.; McNiven, M.A. Mammalian Dynamin-like Protein DLP1 Tubulates Membranes. Mol. Biol. Cell 2001, 12, 2894-2905. [CrossRef]

156. Lee, J.E.; Westrate, L.M.; Wu, H.; Page, C.; Voeltz, G.K. Multiple Dynamin Family Members Collaborate to Drive Mitochondrial Division. Nature 2016, 540, 139-143. [CrossRef]

157. Cho, B.; Cho, H.M.; Jo, Y.; Kim, H.D.; Song, M.; Moon, C.; Kim, H.; Kim, K.; Sesaki, H.; Rhyu, I.J.; et al. Constriction of the Mitochondrial Inner Compartment Is a Priming Event for Mitochondrial Division. Nat. Commun. 2017, 8. [CrossRef] [PubMed]

158. Chakrabarti, R.; Ji, W.-K.; Stan, R.V.; de Juan-Sanz, J.; Ryan, T.A.; Higgs, H.N. INF2-Mediated Actin Polymerization at the ER Stimulates Mitochondrial Calcium Uptake, Inner Membrane Constriction, and Division. J. Cell Biol. 2017, 217, 251-268. [CrossRef] [PubMed]

159. Waterham, H.R.; Koster, J.; van Roermund, C.W.T.; Mooyer, P.A.W.; Wanders, R.J.A.; Leonard, J.V. A Lethal Defect of Mitochondrial and Peroxisomal Fission N. Engl. J. Med. 2007, 356:1736-1741, doi/10.1056/NEJMoa064436. 2007, 356, 1736-1741. [PubMed]

160. Koch, A.; Thiemann, M.; Grabenbauer, M.; Yoon, Y.; McNiven, M.A.; Schrader, M. Dynamin-like Protein 1 Is Involved in Peroxisomal Fission. J. Biol. Chem. 2003, 278, 8597-8605. [CrossRef]

161. Li, X.; Gould, S.J. The Dynamin-like GTPase DLP1 Is Essential for Peroxisome Division and Is Recruited to Peroxisomes in Part by PEX11. J. Biol. Chem. 2003, 278, 17012-17020. [CrossRef] [PubMed]

162. Pitts, K.R.; Yoon, Y.; Krueger, E.W.; McNiven, M.A. The Dynamin-like Protein DLP1 Is Essential for Normal Distribution and Morphology of the Endoplasmic Reticulum and Mitochondria in Mammalian Cells. MBoC 1999, 10, 4403-4417. [CrossRef] [PubMed]

163. Smirnova, E.; Griparic, L.; Shurland, D.L.; van der Bliek, A.M. Dynamin-Related Protein Drp1 Is Required for Mitochondrial Division in Mammalian Cells. Mol. Biol. Cell 2001, 12, 2245-2256. [CrossRef] [PubMed] 
164. Vanstone, J.R.; Smith, A.M.; McBride, S.; Naas, T.; Holcik, M.; Antoun, G.; Harper, M.-E.; Michaud, J.; Sell, E.; Chakraborty, P.; et al. DNM1L- Related Mitochondrial Fission Defect Presenting as Refractory Epilepsy. Eur. J. Hum. Genet. 2016, 24, 1084-1088. [CrossRef] [PubMed]

165. Sheffer, R.; Douiev, L.; Edvardson, S.; Shaag, A.; Tamimi, K.; Soiferman, D.; Meiner, V.; Saada, A. Postnatal Microcephaly and Pain Insensitivity Due to a de Novo Heterozygous DNM1L Mutation Causing Impaired Mitochondrial Fission and Function. Am. J. Med. Genet. Part A 2016, 170, 1603-1607. [CrossRef] [PubMed]

166. Fahrner, J.A.; Liu, R.; Perry, M.S.; Klein, J.; Chan, D.C. A Novel de Novo Dominant Negative Mutation in DNM1L Impairs Mitochondrial Fission and Presents as Childhood Epileptic Encephalopathy. Am. J. Med. Genet. A 2016, 170, 2002-2011. [CrossRef]

167. Vandeleur, D.; Chen, C.V.; Huang, E.J.; Connolly, A.J.; Sanchez, H.; Moon-Grady, A.J. Novel and Lethal Case of Cardiac Involvement in DNM1L Mitochondrial Encephalopathy. Am. J. Med. Genet. Part A 2019, 179, 2486-2489. [CrossRef] [PubMed]

168. Verrigni, D.; di Nottia, M.; Ardissone, A.; Baruffini, E.; Nasca, A.; Legati, A.; Bellacchio, E.; Fagiolari, G.; Martinelli, D.; Fusco, L.; et al. Clinical-Genetic Features and Peculiar Muscle Histopathology in Infantile DNM1L-Related Mitochondrial Epileptic Encephalopathy. Hum. Mutat. 2019, 40, 601-618. [CrossRef]

169. Longo, F.; Benedetti, S.; Zambon, A.A.; Sora, M.G.N.; di Resta, C.; de Ritis, D.; Quattrini, A.; Maltecca, F.; Ferrari, M.; Previtali, S.C. Impaired Turnover of Hyperfused Mitochondria in Severe Axonal Neuropathy Due to a Novel DRP1 Mutation. Hum. Mo.l Genet. 2020, 29, 177-188. [CrossRef] [PubMed]

170. Yoon, G.; Malam, Z.; Paton, T.; Marshall, C.R.; Hyatt, E.; Ivakine, Z.; Scherer, S.W.; Lee, K.-S.; Hawkins, C.; Cohn, R.D.; et al. Lethal Disorder of Mitochondrial Fission Caused by Mutations in DNM1L. J. Pediatrics 2016, 171, 313-316.e2. [CrossRef]

171. Nasca, A.; Legati, A.; Baruffini, E.; Nolli, C.; Moroni, I.; Ardissone, A.; Goffrini, P.; Ghezzi, D. Biallelic Mutations in DNM1L Are Associated with a Slowly Progressive Infantile Encephalopathy. Hum. Mutat. 2016, 37, 898-903. [CrossRef] [PubMed]

172. Gerber, S.; Charif, M.; Chevrollier, A.; Chaumette, T.; Angebault, C.; Kane, M.S.; Paris, A.; Alban, J.; Quiles, M.; Delettre, C.; et al. Mutations in DNM1L, as in OPA1, Result in Dominant Optic Atrophy despite Opposite Effects on Mitochondrial Fusion and Fission. Brain 2017, 140, 2586-2596. [CrossRef] [PubMed]

173. Shamseldin, H.E.; Alshammari, M.; Al-Sheddi, T.; Salih, M.A.; Alkhalidi, H.; Kentab, A.; Repetto, G.M.; Hashem, M.; Alkuraya, F.S. Genomic Analysis of Mitochondrial Diseases in a Consanguineous Population Reveals Novel Candidate Disease Genes. J. Med. Genet. 2012, 49, 234-241. [CrossRef]

174. Koch, J.; Feichtinger, R.G.; Freisinger, P.; Pies, M.; Schrödl, F.; Iuso, A.; Sperl, W.; Mayr, J.A.; Prokisch, H.; Haack, T.B. Disturbed Mitochondrial and Peroxisomal Dynamics Due to Loss of MFF Causes Leigh-like Encephalopathy, Optic Atrophy and Peripheral Neuropathy. J. Med. Genet. 2016, 53, 270-278. [CrossRef]

175. Charif, M.; Wong, Y.C.; Kim, S.; Guichet, A.; Vignal, C.; Zanlonghi, X.; Bensaid, P.; Procaccio, V.; Bonneau, D.; Amati-Bonneau, P.; et al. Dominant Mutations in MIEF1 Affect Mitochondrial Dynamics and Cause a Singular Late Onset Optic Neuropathy. Mol. Neurodegener. 2021, 16, 12. [CrossRef]

176. Marco, A.; Cuesta, A.; Pedrola, L.; Palau, F.; Marín, I. Evolutionary and Structural Analyses of GDAP1, Involved in CharcotMarie-Tooth Disease, Characterize a Novel Class of Glutathione Transferase-Related Genes. Mol. Biol. Evol. 2004, $21,176-187$. [CrossRef] [PubMed]

177. Niemann, A.; Ruegg, M.; la Padula, V.; Schenone, A.; Suter, U. Ganglioside-Induced Differentiation Associated Protein 1 Is a Regulator of the Mitochondrial Network: New Implications for Charcot-Marie-Tooth Disease. J. Cell Biol. 2005, 170, $1067-1078$. [CrossRef]

178. Baxter, R.V.; Ben-Othmane, K.; Rochelle, J.M.; Stajich, J.E.; Hulette, C.; Dew-Knight, S.; Hentati, F.; Ben Hamida, M.; Bel, S.; Stenger, J.E.; et al. Ganglioside-Induced Differentiation-Associated Protein-1 Is Mutant in Charcot-Marie-Tooth Disease Type 4A/8q21. Nat. Genet. 2002, 30, 21-22. [CrossRef]

179. Claramunt, R.; Pedrola, L.; Sevilla, T.; de Munain, A.L.; Berciano, J.; Cuesta, A.; Sánchez-Navarro, B.; Millán, J.M.; Saifi, G.M.; Lupski, J.R.; et al. Genetics of Charcot-Marie-Tooth Disease Type 4A: Mutations, Inheritance, Phenotypic Variability, and Founder Effect. J. Med. Genet. 2005, 42, 358-365. [CrossRef]

180. Niemann, A.; Wagner, K.M.; Ruegg, M.; Suter, U. GDAP1 Mutations Differ in Their Effects on Mitochondrial Dynamics and Apoptosis Depending on the Mode of Inheritance. Neurobiol. Dis. 2009, 36, 509-520. [CrossRef] [PubMed]

181. Pla-Martín, D.; Rueda, C.B.; Estela, A.; Sánchez-Piris, M.; González-Sánchez, P.; Traba, J.; de la Fuente, S.; Scorrano, L.; RenauPiqueras, J.; Alvarez, J.; et al. Silencing of the Charcot-Marie-Tooth Disease-Associated Gene GDAP1 Induces Abnormal Mitochondrial Distribution and Affects Ca2+ Homeostasis by Reducing Store-Operated Ca2+ Entry. Neurobiol. Dis. 2013, 55, 140-151. [CrossRef] [PubMed]

182. Civera-Tregón, A.; Domínguez, L.; Martínez-Valero, P.; Serrano, C.; Vallmitjana, A.; Benítez, R.; Hoenicka, J.; Satrústegui, J.; Palau, F. Mitochondria and Calcium Defects Correlate with Axonal Dysfunction in GDAP1-Related Charcot-Marie-Tooth Mouse Model. Neurobiol. Dis. 2021, 105300. [CrossRef] [PubMed]

183. Barneo-Muñoz, M.; Juárez, P.; Civera-Tregón, A.; Yndriago, L.; Pla-Martin, D.; Zenker, J.; Cuevas-Martín, C.; Estela, A.; SánchezAragó, M.; Forteza-Vila, J.; et al. Lack of GDAP1 Induces Neuronal Calcium and Mitochondrial Defects in a Knockout Mouse Model of Charcot-Marie-Tooth Neuropathy. PLoS Genet. 2015, 11, e1005115. [CrossRef] [PubMed]

184. Bartsakoulia, M.; Pyle, A.; Troncoso-Chandía, D.; Vial-Brizzi, J.; Paz-Fiblas, M.V.; Duff, J.; Griffin, H.; Boczonadi, V.; Lochmüller, H.; Kleinle, S.; et al. A Novel Mechanism Causing Imbalance of Mitochondrial Fusion and Fission in Human Myopathies. Hum. Mol. Genet. 2018, 27, 1186-1195. [CrossRef] [PubMed] 
185. Bitoun, M.; Maugenre, S.; Jeannet, P.-Y.; Lacène, E.; Ferrer, X.; Laforêt, P.; Martin, J.-J.; Laporte, J.; Lochmüller, H.; Beggs, A.H.; et al. Mutations in Dynamin 2 Cause Dominant Centronuclear Myopathy. Nat. Genet. 2005, 37, 1207-1209. [CrossRef]

186. Züchner, S.; Noureddine, M.; Kennerson, M.; Verhoeven, K.; Claeys, K.; Jonghe, P.D.; Merory, J.; Oliveira, S.A.; Speer, M.C.; Stenger, J.E.; et al. Mutations in the Pleckstrin Homology Domain of Dynamin 2 Cause Dominant Intermediate Charcot-Marie-Tooth Disease. Nat. Genet. 2005, 37, 289-294. [CrossRef]

187. Claeys, K.G.; Züchner, S.; Kennerson, M.; Berciano, J.; Garcia, A.; Verhoeven, K.; Storey, E.; Merory, J.R.; Bienfait, H.M.E.; Lammens, M.; et al. Phenotypic Spectrum of Dynamin 2 Mutations in Charcot-Marie-Tooth Neuropathy. Brain 2009, 132, 1741-1752. [CrossRef]

188. Koutsopoulos, O.S.; Kretz, C.; Weller, C.M.; Roux, A.; Mojzisova, H.; Böhm, J.; Koch, C.; Toussaint, A.; Heckel, E.; Stemkens, D.; et al. Dynamin 2 Homozygous Mutation in Humans with a Lethal Congenital Syndrome. Eur. J. Hum. Genet. 2013, 21, 637-642. [CrossRef] [PubMed]

189. Brown, E.J.; Schlöndorff, J.S.; Becker, D.J.; Tsukaguchi, H.; Tonna, S.J.; Uscinski, A.L.; Higgs, H.N.; Henderson, J.M.; Pollak, M.R. Mutations in the Formin Gene INF2 Cause Focal Segmental Glomerulosclerosis. Nat. Genet. 2009, 42, 72-76. [CrossRef] [PubMed]

190. Boyer, O.; Nevo, F.; Plaisier, E.; Funalot, B.; Gribouval, O.; Benoit, G.; Cong, E.H.; Arrondel, C.; Tête, M.-J.; Montjean, R.; et al. INF2 Mutations in Charcot-Marie-Tooth Disease with Glomerulopathy. N. Engl. J. Med. 2011, 365, 2377-2388. [CrossRef]

191. Csordás, G.; Renken, C.; Várnai, P.; Walter, L.; Weaver, D.; Buttle, K.F.; Balla, T.; Mannella, C.A.; Hajnóczky, G. Structural and Functional Features and Significance of the Physical Linkage between ER and Mitochondria. J. Cell Biol. 2006, 174, 915-921. [CrossRef]

192. Vance, J.E. MAM (Mitochondria-Associated Membranes) in Mammalian Cells: Lipids and Beyond. Biochim. Biophys. Acta 2014, 1841, 595-609. [CrossRef]

193. Kornmann, B.; Currie, E.; Collins, S.R.; Schuldiner, M.; Nunnari, J.; Weissman, J.S.; Walter, P. An ER-Mitochondria Tethering Complex Revealed by a Synthetic Biology Screen. Science 2009, 325, 477-481. [CrossRef] [PubMed]

194. Sugiura, A.; Nagashima, S.; Tokuyama, T.; Amo, T.; Matsuki, Y.; Ishido, S.; Kudo, Y.; McBride, H.M.; Fukuda, T.; Matsushita, N.; et al. MITOL Regulates Endoplasmic Reticulum-Mitochondria Contacts via Mitofusin2. Mol. Cell 2013, 51, 20-34. [CrossRef] [PubMed]

195. Szabadkai, G.; Bianchi, K.; Várnai, P.; de Stefani, D.; Wieckowski, M.R.; Cavagna, D.; Nagy, A.I.; Balla, T.; Rizzuto, R. ChaperoneMediated Coupling of Endoplasmic Reticulum and Mitochondrial Ca2+ Channels. J. Cell Biol. 2006, 175, 901-911. [CrossRef] [PubMed]

196. Simmen, T.; Aslan, J.E.; Blagoveshchenskaya, A.D.; Thomas, L.; Wan, L.; Xiang, Y.; Feliciangeli, S.F.; Hung, C.-H.; Crump, C.M.; Thomas, G. PACS-2 Controls Endoplasmic Reticulum-Mitochondria Communication and Bid-Mediated Apoptosis. EMBO J. 2005, 24, 717-729. [CrossRef]

197. Rizzuto, R.; Pinton, P.; Carrington, W.; Fay, F.S.; Fogarty, K.E.; Lifshitz, L.M.; Tuft, R.A.; Pozzan, T. Close Contacts with the Endoplasmic Reticulum as Determinants of Mitochondrial Ca2+ Responses. Science 1998, 280, 1763-1766. [CrossRef] [PubMed]

198. Patergnani, S.; Suski, J.M.; Agnoletto, C.; Bononi, A.; Bonora, M.; de Marchi, E.; Giorgi, C.; Marchi, S.; Missiroli, S.; Poletti, F.; et al. Calcium Signaling around Mitochondria Associated Membranes (MAMs). Cell Commun. Signal. 2011, 9, 19. [CrossRef]

199. Honrath, B.; Metz, I.; Bendridi, N.; Rieusset, J.; Culmsee, C.; Dolga, A.M. Glucose-Regulated Protein 75 Determines ERMitochondrial Coupling and Sensitivity to Oxidative Stress in Neuronal Cells. Cell Death Discov. 2017, 3, 1-13. [CrossRef]

200. Hayashi, T.; Su, T.-P. Sigma-1 Receptor Chaperones at the ER- Mitochondrion Interface Regulate Ca2+ Signaling and Cell Survival. Cell 2007, 131, 596-610. [CrossRef]

201. Kumar, V.; Maity, S. ER Stress-Sensor Proteins and ER-Mitochondrial Crosstalk-Signaling Beyond (ER) Stress Response. Biomolecules 2021, 11, 173. [CrossRef] [PubMed]

202. De Stefani, D.; Raffaello, A.; Teardo, E.; Szabò, I.; Rizzuto, R. A Forty-Kilodalton Protein of the Inner Membrane Is the Mitochondrial Calcium Uniporter. Nature 2011, 476, 336-340. [CrossRef]

203. Baughman, J.M.; Perocchi, F.; Girgis, H.S.; Plovanich, M.; Belcher-Timme, C.A.; Sancak, Y.; Bao, X.R.; Strittmatter, L.; Goldberger, O.; Bogorad, R.L.; et al. Integrative Genomics Identifies MCU as an Essential Component of the Mitochondrial Calcium Uniporter. Nature 2011, 476, 341-345. [CrossRef] [PubMed]

204. Singh, S.; Mabalirajan, U. Mitochondrial Calcium in Command of Juggling Myriads of Cellular Functions. Mitochondrion 2021, 57, 108-118. [CrossRef] [PubMed]

205. Denton, R.M.; Randle, P.J.; Martin, B.R. Stimulation by Calcium Ions of Pyruvate Dehydrogenase Phosphate Phosphatase. Biochem J. 1972, 128, 161-163. [CrossRef] [PubMed]

206. McCormack, J.G.; Halestrap, A.P.; Denton, R.M. Role of Calcium Ions in Regulation of Mammalian Intramitochondrial Metabolism. Physiol. Rev. 1990, 70, 391-425. [CrossRef]

207. Giorgi, C.; Marchi, S.; Pinton, P. The Machineries, Regulation and Cellular Functions of Mitochondrial Calcium. Nat. Rev. Mol. Cell Biol. 2018, 19, 713-730. [CrossRef] [PubMed]

208. Guerrero-Hernandez, A.; Verkhratsky, A. Calcium Signalling in Diabetes. Cell Calcium 2014, 56, 297-301. [CrossRef] [PubMed]

209. Gilon, P.; Chae, H.-Y.; Rutter, G.A.; Ravier, M.A. Calcium Signaling in Pancreatic $\beta$-Cells in Health and in Type 2 Diabetes. Cell Calcium 2014, 56, 340-361. [CrossRef] [PubMed]

210. Tatsuta, T.; Scharwey, M.; Langer, T. Mitochondrial Lipid Trafficking. Trends Cell Biol. 2014, 24, 44-52. [CrossRef] 
211. Zhang, Q.; Tamura, Y.; Roy, M.; Adachi, Y.; Iijima, M.; Sesaki, H. Biosynthesis and Roles of Phospholipids in Mitochondrial Fusion, Division and Mitophagy. Cell Mol. Life Sci 2014, 71, 3767-3778. [CrossRef]

212. Potting, C.; Tatsuta, T.; König, T.; Haag, M.; Wai, T.; Aaltonen, M.J.; Langer, T. TRIAP1/PRELI Complexes Prevent Apoptosis by Mediating Intramitochondrial Transport of Phosphatidic Acid. Cell Metab. 2013, 18, 287-295. [CrossRef]

213. Miliara, X.; Tatsuta, T.; Berry, J.-L.; Rouse, S.L.; Solak, K.; Chorev, D.S.; Wu, D.; Robinson, C.V.; Matthews, S.; Langer, T. Structural Determinants of Lipid Specificity within Ups/PRELI Lipid Transfer Proteins. Nat. Commun. 2019, 10, 1130. [CrossRef]

214. Hernández-Alvarez, M.I.; Sebastián, D.; Vives, S.; Ivanova, S.; Bartoccioni, P.; Kakimoto, P.; Plana, N.; Veiga, S.R.; Hernández, V.; Vasconcelos, N.; et al. Deficient Endoplasmic Reticulum-Mitochondrial Phosphatidylserine Transfer Causes Liver Disease. Cell 2019, 177, 881-895.e17. [CrossRef]

215. Horibata, Y.; Sugimoto, H. StarD7 Mediates the Intracellular Trafficking of Phosphatidylcholine to Mitochondria*. J. Biol. Chem. 2010, 285, 7358-7365. [CrossRef] [PubMed]

216. Saita, S.; Tatsuta, T.; Lampe, P.A.; König, T.; Ohba, Y.; Langer, T. PARL Partitions the Lipid Transfer Protein STARD7 between the Cytosol and Mitochondria. EMBO J. 2018, 37, e97909. [CrossRef] [PubMed]

217. Endo, T.; Tamura, Y. Shuttle Mission in the Mitochondrial Intermembrane Space. EMBO J. 2018, 37, e98993. [CrossRef] [PubMed]

218. Schug, Z.T.; Gottlieb, E. Cardiolipin Acts as a Mitochondrial Signalling Platform to Launch Apoptosis. Biochim. Et Biophys. Acta Biomembr. 2009, 1788, 2022-2031. [CrossRef] [PubMed]

219. Janikiewicz, J.; Szymański, J.; Malinska, D.; Patalas-Krawczyk, P.; Michalska, B.; Duszyński, J.; Giorgi, C.; Bonora, M.; Dobrzyn, A.; Wieckowski, M.R. Mitochondria-Associated Membranes in Aging and Senescence: Structure, Function, and Dynamics. Cell Death Dis. 2018, 9, 1-12. [CrossRef] [PubMed]

220. Hamasaki, M.; Furuta, N.; Matsuda, A.; Nezu, A.; Yamamoto, A.; Fujita, N.; Oomori, H.; Noda, T.; Haraguchi, T.; Hiraoka, Y.; et al. Autophagosomes Form at ER-Mitochondria Contact Sites. Nature 2013, 495, 389-393. [CrossRef]

221. Hsu, P.; Shi, Y. Regulation of Autophagy by Mitochondrial Phospholipids in Health and Diseases. Biochim Biophys Acta Mol. Cell Biol. Lipids 2017, 1862, 114-129. [CrossRef]

222. Sawyer, S.L.; Cheuk-Him Ng, A.; Innes, A.M.; Wagner, J.D.; Dyment, D.A.; Tetreault, M.; Care4Rare Canada Consortium; Majewski, J.; Boycott, K.M.; Screaton, R.A.; et al. Homozygous Mutations in MFN2 Cause Multiple Symmetric Lipomatosis Associated with Neuropathy. Hum. Mol. Genet. 2015, 24, 5109-5114. [CrossRef]

223. Rocha, N.; Bulger, D.A.; Frontini, A.; Titheradge, H.; Gribsholt, S.B.; Knox, R.; Page, M.; Harris, J.; Payne, F.; Adams, C.; et al. Human Biallelic MFN2 Mutations Induce Mitochondrial Dysfunction, Upper Body Adipose Hyperplasia, and Suppression of Leptin Expression. eLife 2017, 6, e23813. [CrossRef]

224. Capel, E.; Vatier, C.; Cervera, P.; Stojkovic, T.; Disse, E.; Cottereau, A.-S.; Auclair, M.; Verpont, M.-C.; Mosbah, H.; Gourdy, P.; et al. MFN2-Associated Lipomatosis: Clinical Spectrum and Impact on Adipose Tissue. J. Clin. Lipidol. 2018, 12, 1420-1435. [CrossRef] [PubMed]

225. Chung, K.-P.; Hsu, C.-L.; Fan, L.-C.; Huang, Z.; Bhatia, D.; Chen, Y.-J.; Hisata, S.; Cho, S.J.; Nakahira, K.; Imamura, M.; et al. Mitofusins Regulate Lipid Metabolism to Mediate the Development of Lung Fibrosis. Nat. Commun. 2019, 10, 3390. [CrossRef]

226. Boutant, M.; Kulkarni, S.S.; Joffraud, M.; Ratajczak, J.; Valera-Alberni, M.; Combe, R.; Zorzano, A.; Cantó, C. Mfn2 Is Critical for Brown Adipose Tissue Thermogenic Function. EMBO J. 2017, 36, 1543-1558. [CrossRef]

227. Ding, Y.; Gao, H.; Zhao, L.; Wang, X.; Zheng, M. Mitofusin 2-Deficiency Suppresses Cell Proliferation through Disturbance of Autophagy. PLoS ONE 2015, 10, e0121328. [CrossRef]

228. Zhao, T.; Huang, X.; Han, L.; Wang, X.; Cheng, H.; Zhao, Y.; Chen, Q.; Chen, J.; Cheng, H.; Xiao, R.; et al. Central Role of Mitofusin 2 in Autophagosome-Lysosome Fusion in Cardiomyocytes. J. Biol. Chem 2012, 287, 23615-23625. [CrossRef]

229. Li, J.; Liu, X.; Wang, H.; Zhang, W.; Chan, D.C.; Shi, Y. Lysocardiolipin Acyltransferase 1 (ALCAT1) Controls Mitochondrial DNA Fidelity and Biogenesis through Modulation of MFN2 Expression. Proc. Natl. Acad. Sci. USA 2012, 109, 6975-6980. [CrossRef] [PubMed]

230. Li, J.; Romestaing, C.; Han, X.; Li, Y.; Hao, X.; Wu, Y.; Sun, C.; Liu, X.; Jefferson, L.S.; Xiong, J.; et al. Cardiolipin Remodeling by ALCAT1 Links Oxidative Stress and Mitochondrial Dysfunction to Obesity. Cell Metab. 2010, 12, 154-165. [CrossRef] [PubMed]

231. Wang, L.; Liu, X.; Nie, J.; Zhang, J.; Kimball, S.R.; Zhang, H.; Zhang, W.J.; Jefferson, L.S.; Cheng, Z.; Ji, Q.; et al. ALCAT1 Controls Mitochondrial Etiology of Fatty Liver Diseases, Linking Defective Mitophagy to Steatosis. Hepatology 2015, 61, 486-496. [CrossRef]

232. Bilguvar, K.; Tyagi, N.K.; Ozkara, C.; Tuysuz, B.; Bakircioglu, M.; Choi, M.; Delil, S.; Caglayan, A.O.; Baranoski, J.F.; Erturk, O.; et al. Recessive Loss of Function of the Neuronal Ubiquitin Hydrolase UCHL1 Leads to Early-Onset Progressive Neurodegeneration. Proc. Natl. Acad. Sci. USA 2013, 110, 3489-3494. [CrossRef]

233. Rydning, S.L.; Backe, P.H.; Sousa, M.M.L.; Iqbal, Z.; Øye, A.-M.; Sheng, Y.; Yang, M.; Lin, X.; Slupphaug, G.; Nordenmark, T.H.; et al. Novel UCHL1 Mutations Reveal New Insights into Ubiquitin Processing. Hum. Mol. Genet. 2017, 26, 1031-1040. [CrossRef]

234. Yamazaki, K.; Wakasugi, N.; Tomita, T.; Kikuchi, T.; Mukoyama, M.; Ando, K. Gracile Axonal Dystrophy (GAD), a New Neurological Mutant in the Mouse. Proc. Soc. Exp. Biol. Med. 1988, 187, 209-215. [CrossRef]

235. Chen, F.; Sugiura, Y.; Myers, K.G.; Liu, Y.; Lin, W. Ubiquitin Carboxyl-Terminal Hydrolase L1 Is Required for Maintaining the Structure and Function of the Neuromuscular Junction. PNAS 2010, 107, 1636-1641. [CrossRef] 
236. Cerqueira, F.M.; von Stockum, S.; Giacomello, M.; Goliand, I.; Kakimoto, P.; Marchesan, E.; de Stefani, D.; Kowaltowski, A.J.; Ziviani, E.; Shirihai, O.S. A New Target for an Old DUB: UCH-L1 Regulates Mitofusin-2 Levels, Altering Mitochondrial Morphology, Function and Calcium Uptake. Redox Biol. 2020, 37, 101676. [CrossRef] [PubMed]

237. Poston, C.N.; Krishnan, S.C.; Bazemore-Walker, C.R. In-Depth Proteomic Analysis of Mammalian Mitochondria-Associated Membranes (MAM). J. Proteom. 2013, 79, 219-230. [CrossRef] [PubMed]

238. Liu, Z.; Meray, R.K.; Grammatopoulos, T.N.; Fredenburg, R.A.; Cookson, M.R.; Liu, Y.; Logan, T.; Lansbury, P.T. MembraneAssociated Farnesylated UCH-L1 Promotes $\alpha$-Synuclein Neurotoxicity and Is a Therapeutic Target for Parkinson's Disease. PNAS 2009, 106, 4635-4640. [CrossRef]

239. Costes, S.; Huang, C.; Gurlo, T.; Daval, M.; Matveyenko, A.V.; Rizza, R.A.; Butler, A.E.; Butler, P.C. $\beta$-Cell Dysfunctional ERAD/Ubiquitin/Proteasome System in Type 2 Diabetes Mediated by Islet Amyloid Polypeptide-Induced UCH-L1 Deficiency. Diabetes 2011, 60, 227-238. [CrossRef]

240. Petrinovic, M.M.; Duncan, C.S.; Bourikas, D.; Weinman, O.; Montani, L.; Schroeter, A.; Maerki, D.; Sommer, L.; Stoeckli, E.T.; Schwab, M.E. Neuronal Nogo-A Regulates Neurite Fasciculation, Branching and Extension in the Developing Nervous System. Development 2010, 137, 2539-2550. [CrossRef]

241. Rigoli, L.; Bramanti, P.; di Bella, C.; de Luca, F. Genetic and Clinical Aspects of Wolfram Syndrome 1, a Severe Neurodegenerative Disease. Pediatric Res. 2018, 83, 921-929. [CrossRef] [PubMed]

242. Inoue, H.; Tanizawa, Y.; Wasson, J.; Behn, P.; Kalidas, K.; Bernal-Mizrachi, E.; Mueckler, M.; Marshall, H.; Donis-Keller, H.; Crock, P.; et al. A Gene Encoding a Transmembrane Protein Is Mutated in Patients with Diabetes Mellitus and Optic Atrophy (Wolfram Syndrome). Nat. Genet. 1998, 20, 143-148. [CrossRef]

243. Strom, T.M.; Hörtnagel, K.; Hofmann, S.; Gekeler, F.; Scharfe, C.; Rabl, W.; Gerbitz, K.D.; Meitinger, T. Diabetes Insipidus, Diabetes Mellitus, Optic Atrophy and Deafness (DIDMOAD) Caused by Mutations in a Novel Gene (Wolframin) Coding for a Predicted Transmembrane Protein. Hum. Mol. Genet. 1998, 7, 2021-2028. [CrossRef]

244. Osman, A.A.; Saito, M.; Makepeace, C.; Permutt, M.A.; Schlesinger, P.; Mueckler, M. Wolframin Expression Induces Novel Ion Channel Activity in Endoplasmic Reticulum Membranes and Increases Intracellular Calcium. J. Biol. Chem. 2003, 278, 52755-52762. [CrossRef]

245. Fonseca, S.G.; Fukuma, M.; Lipson, K.L.; Nguyen, L.X.; Allen, J.R.; Oka, Y.; Urano, F. WFS1 Is a Novel Component of the Unfolded Protein Response and Maintains Homeostasis of the Endoplasmic Reticulum in Pancreatic $\beta$-Cells. J. Biol. Chem. 2005, 280, 39609-39615. [CrossRef]

246. Fonseca, S.G.; Ishigaki, S.; Oslowski, C.M.; Lu, S.; Lipson, K.L.; Ghosh, R.; Hayashi, E.; Ishihara, H.; Oka, Y.; Permutt, M.A.; et al. Wolfram Syndrome 1 Gene Negatively Regulates ER Stress Signaling in Rodent and Human Cells. J. Clin. Invest. 2010, 120, 744-755. [CrossRef] [PubMed]

247. Delprat, B.; Maurice, T.; Delettre, C. Wolfram Syndrome: MAMs' Connection? Cell Death Dis. 2018, 9, 1-13. [CrossRef] [PubMed]

248. Grenier, J.; Meunier, I.; Daien, V.; Baudoin, C.; Halloy, F.; Bocquet, B.; Blanchet, C.; Delettre, C.; Esmenjaud, E.; Roubertie, A.; et al. WFS1 in Optic Neuropathies: Mutation Findings in Nonsyndromic Optic Atrophy and Assessment of Clinical Severity. Ophthalmology 2016, 123, 1989-1998. [CrossRef]

249. Amr, S.; Heisey, C.; Zhang, M.; Xia, X.-J.; Shows, K.H.; Ajlouni, K.; Pandya, A.; Satin, L.S.; El-Shanti, H.; Shiang, R. A Homozygous Mutation in a Novel Zinc-Finger Protein, ERIS, Is Responsible for Wolfram Syndrome 2. Am. J. Hum. Genet. 2007, 81, 673-683. [CrossRef] [PubMed]

250. Mozzillo, E.; Delvecchio, M.; Carella, M.; Grandone, E.; Palumbo, P.; Salina, A.; Aloi, C.; Buono, P.; Izzo, A.; D’ Annunzio, G.; et al. A Novel CISD2 Intragenic Deletion, Optic Neuropathy and Platelet Aggregation Defect in Wolfram Syndrome Type 2. BMC Med. Genet. 2014, 15, 88. [CrossRef]

251. Wiley, S.E.; Andreyev, A.Y.; Divakaruni, A.S.; Karisch, R.; Perkins, G.; Wall, E.A.; van der Geer, P.; Chen, Y.-F.; Tsai, T.-F.; Simon, M.I.; et al. Wolfram Syndrome Protein, Miner1, Regulates Sulphydryl Redox Status, the Unfolded Protein Response, and Ca2+ Homeostasis. EMBO Mol. Med. 2013, 5, 904-918. [CrossRef] [PubMed]

252. El-Shanti, H.; Lidral, A.C.; Jarrah, N.; Druhan, L.; Ajlouni, K. Homozygosity Mapping Identifies an Additional Locus for Wolfram Syndrome on Chromosome 4q. Am. J. Hum. Genet. 2000, 66, 1229-1236. [CrossRef]

253. Rouzier, C.; Moore, D.; Delorme, C.; Lacas-Gervais, S.; Ait-El-Mkadem, S.; Fragaki, K.; Burté, F.; Serre, V.; Bannwarth, S.; Chaussenot, A.; et al. A Novel CISD2 Mutation Associated with a Classical Wolfram Syndrome Phenotype Alters Ca2+ Homeostasis and ER-Mitochondria Interactions. Hum. Mol. Genet. 2017, 26, 1599-1611. [CrossRef]

254. Cagalinec, M.; Liiv, M.; Hodurova, Z.; Hickey, M.A.; Vaarmann, A.; Mandel, M.; Zeb, A.; Choubey, V.; Kuum, M.; Safiulina, D.; et al. Role of Mitochondrial Dynamics in Neuronal Development: Mechanism for Wolfram Syndrome. PLoS Biol. 2016, 14, e1002511. [CrossRef] [PubMed]

255. Hara, T.; Mahadevan, J.; Kanekura, K.; Hara, M.; Lu, S.; Urano, F. Calcium Efflux from the Endoplasmic Reticulum Leads to $\beta$-Cell Death. Endocrinology 2014, 155, 758-768. [CrossRef]

256. Lu, S.; Kanekura, K.; Hara, T.; Mahadevan, J.; Spears, L.D.; Oslowski, C.M.; Martinez, R.; Yamazaki-Inoue, M.; Toyoda, M.; Neilson, A.; et al. A Calcium-Dependent Protease as a Potential Therapeutic Target for Wolfram Syndrome. PNAS 2014, 111, E5292-E5301. [CrossRef] [PubMed]

257. Abreu, D.; Asada, R.; Revilla, J.M.P.; Lavagnino, Z.; Kries, K.; Piston, D.W.; Urano, F. Wolfram Syndrome 1 Gene Regulates Pathways Maintaining Beta-Cell Health and Survival. Lab. Invest. 2020, 100, 849-862. [CrossRef] [PubMed] 
258. Wersinger, D.B.; Benkafadar, N.; Jagodzinska, J.; Hamel, C.; Tanizawa, Y.; Lenaers, G.; Delettre, C. Impairment of Visual Function and Retinal ER Stress Activation in Wfs1-Deficient Mice. PLoS ONE 2014, 9, e97222. [CrossRef]

259. Kanekura, K.; Ma, X.; Murphy, J.T.; Zhu, L.J.; Diwan, A.; Urano, F. IRE1 Prevents Endoplasmic Reticulum Membrane Permeabilization and Cell Death under Pathological Conditions. Sci. Signal. 2015, 8, ra62. [CrossRef]

260. Chen, Y.-F.; Kao, C.-H.; Chen, Y.-T.; Wang, C.-H.; Wu, C.-Y.; Tsai, C.-Y.; Liu, F.-C.; Yang, C.-W.; Wei, Y.-H.; Hsu, M.-T.; et al. Cisd2 Deficiency Drives Premature Aging and Causes Mitochondria-Mediated Defects in Mice. Genes Dev. 2009, 23, 1183-1194. [CrossRef]

261. Lugar, H.M.; Koller, J.M.; Rutlin, J.; Marshall, B.A.; Kanekura, K.; Urano, F.; Bischoff, A.N.; Shimony, J.S.; Hershey, T.; Washington University Wolfram Syndrome Research Study Group. Neuroimaging Evidence of Deficient Axon Myelination in Wolfram Syndrome. Sci Rep. 2016, 6, 21167. [CrossRef]

262. Samara, A.; Rahn, R.; Neyman, O.; Park, K.Y.; Samara, A.; Marshall, B.; Dougherty, J.; Hershey, T. Developmental Hypomyelination in Wolfram Syndrome: New Insights from Neuroimaging and Gene Expression Analyses. Orphanet J. Rare Dis 2019, 14, 279. [CrossRef]

263. Anikster, Y.; Kleta, R.; Shaag, A.; Gahl, W.A.; Elpeleg, O. Type III 3-Methylglutaconic Aciduria (Optic Atrophy plus Syndrome, or Costeff Optic Atrophy Syndrome): Identification of the OPA3 Gene and Its Founder Mutation in Iraqi Jews. Am. J. Hum. Genet. 2001, 69, 1218-1224. [CrossRef] [PubMed]

264. Abrams, A.J.; Hufnagel, R.B.; Rebelo, A.; Zanna, C.; Patel, N.; Gonzalez, M.A.; Campeanu, I.J.; Griffin, L.B.; Groenewald, S.; Strickland, A.V.; et al. Mutations in SLC25A46, Encoding a UGO1-like Protein, Cause an Optic Atrophy Spectrum Disorder. Nat. Genet. 2015, 47, 926-932. [CrossRef] [PubMed]

265. Janer, A.; Prudent, J.; Paupe, V.; Fahiminiya, S.; Majewski, J.; Sgarioto, N.; des Rosiers, C.; Forest, A.; Lin, Z.; Gingras, A.; et al. SLC25A46 Is Required for Mitochondrial Lipid Homeostasis and Cristae Maintenance and Is Responsible for Leigh Syndrome. EMBO Mol. Med. 2016, 8, 1019-1038. [CrossRef] [PubMed]

266. Reynier, P.; Amati-Bonneau, P.; Verny, C.; Olichon, A.; Simard, G.; Guichet, A.; Bonnemains, C.; Malecaze, F.; Malinge, M.C.; Pelletier, J.B.; et al. OPA3 Gene Mutations Responsible for Autosomal Dominant Optic Atrophy and Cataract. J. Med. Genet. 2004, 41, e110. [CrossRef]

267. Sergouniotis, P.I.; Perveen, R.; Thiselton, D.L.; Giannopoulos, K.; Sarros, M.; Davies, J.R.; Biswas, S.; Ansons, A.M.; Ashworth, J.L.; Lloyd, I.C.; et al. Clinical and Molecular Genetic Findings in Autosomal Dominant OPA3-Related Optic Neuropathy. Neurogenetics 2015, 16, 69-75. [CrossRef] [PubMed]

268. Horga, A.; Bugiardini, E.; Manole, A.; Bremner, F.; Jaunmuktane, Z.; Dankwa, L.; Rebelo, A.P.; Woodward, C.E.; Hargreaves, I.P.; Cortese, A.; et al. Autosomal Dominant Optic Atrophy and Cataract "plus" Phenotype Including Axonal Neuropathy. Neurol Genet. 2019, 5, e322. [CrossRef] [PubMed]

269. Wan, J.; Steffen, J.; Yourshaw, M.; Mamsa, H.; Andersen, E.; Rudnik-Schöneborn, S.; Pope, K.; Howell, K.B.; McLean, C.A.; Kornberg, A.J.; et al. Loss of Function of SLC25A46 Causes Lethal Congenital Pontocerebellar Hypoplasia. Brain 2016, 139, 2877-2890. [CrossRef]

270. van Dijk, T.; Rudnik-Schöneborn, S.; Senderek, J.; Hajmousa, G.; Mei, H.; Dusl, M.; Aronica, E.; Barth, P.; Baas, F. Pontocerebellar Hypoplasia with Spinal Muscular Atrophy (PCH1): Identification of SLC25A46 Mutations in the Original Dutch PCH1 Family. Brain 2017, 140, e46. [CrossRef]

271. Braunisch, M.C.; Gallwitz, H.; Abicht, A.; Diebold, I.; Holinski-Feder, E.; Maldergem, L.V.; Lammens, M.; Kovács-Nagy, R.; Alhaddad, B.; Strom, T.M.; et al. Extension of the Phenotype of Biallelic Loss-of-Function Mutations in SLC25A46 to the Severe Form of Pontocerebellar Hypoplasia Type I. Clin. Genet. 2018, 93, 255-265. [CrossRef]

272. Bitetto, G.; Malaguti, M.C.; Ceravolo, R.; Monfrini, E.; Straniero, L.; Morini, A.; di Giacopo, R.; Frosini, D.; Palermo, G.; Biella, F.; et al. SLC25A46 Mutations in Patients with Parkinson's Disease and Optic Atrophy. Parkinsonism. Relat. Disord. 2020, 74, 1-5. [CrossRef]

273. Huizing, M.; Dorward, H.; Ly, L.; Klootwijk, E.; Kleta, R.; Skovby, F.; Pei, W.; Feldman, B.; Gahl, W.A.; Anikster, Y. OPA3, Mutated in 3-Methylglutaconic Aciduria Type III, Encodes Two Transcripts Targeted Primarily to Mitochondria. Mol. Genet. Metab. 2010, 100, 149-154. [CrossRef] [PubMed]

274. Ryu, S.-W.; Jeong, H.J.; Choi, M.; Karbowski, M.; Choi, C. Optic Atrophy 3 as a Protein of the Mitochondrial Outer Membrane Induces Mitochondrial Fragmentation. Cell Mol. Life Sci 2010, 67, 2839-2850. [CrossRef]

275. Ryu, S.-W.; Yoon, J.; Yim, N.; Choi, K.; Choi, C. Downregulation of OPA3 Is Responsible for Transforming Growth Factor- $\beta$ Induced Mitochondrial Elongation and F-Actin Rearrangement in Retinal Pigment Epithelial ARPE-19 Cells. PLoS ONE 2013, 8, e63495. [CrossRef]

276. Wells, T.; Davies, J.R.; Guschina, I.A.; Ball, D.J.; Davies, J.S.; Davies, V.J.; Evans, B.A.J.; Votruba, M. Opa3, a Novel Regulator of Mitochondrial Function, Controls Thermogenesis and Abdominal Fat Mass in a Mouse Model for Costeff Syndrome. Hum. Mol. Genet. 2012, 21, 4836-4844. [CrossRef]

277. Bourne, S.C.; Townsend, K.N.; Shyr, C.; Matthews, A.; Lear, S.A.; Attariwala, R.; Lehman, A.; Wasserman, W.W.; van Karnebeek, C.; Sinclair, G.; et al. Optic Atrophy, Cataracts, Lipodystrophy/Lipoatrophy, and Peripheral Neuropathy Caused by a de Novo OPA3 Mutation. Cold Spring Harb Mol. Case Stud. 2017, 3, a001156. [CrossRef] 
278. Steffen, J.; Vashisht, A.A.; Wan, J.; Jen, J.C.; Claypool, S.M.; Wohlschlegel, J.A.; Koehler, C.M. Rapid Degradation of Mutant SLC25A46 by the Ubiquitin-Proteasome System Results in MFN1/2-Mediated Hyperfusion of Mitochondria. Mol. Biol. Cell 2017, 28, 600-612. [CrossRef]

279. Mueller, N.; Sassa, T.; Morales-Gonzalez, S.; Schneider, J.; Salchow, D.J.; Seelow, D.; Knierim, E.; Stenzel, W.; Kihara, A.; Schuelke, M. De Novo Mutation in ELOVL1 Causes Ichthyosis, Acanthosis Nigricans, Hypomyelination, Spastic Paraplegia, High Frequency Deafness and Optic Atrophy. J. Med. Genet. 2019, 56, 164-175. [CrossRef]

280. Kutkowska-Kaźmierczak, A.; Rydzanicz, M.; Chlebowski, A.; Kłosowska-Kosicka, K.; Mika, A.; Gruchota, J.; Jurkiewicz, E.; Kowalewski, C.; Pollak, A.; Stradomska, T.J.; et al. Dominant ELOVL1 Mutation Causes Neurological Disorder with Ichthyotic Keratoderma, Spasticity, Hypomyelination and Dysmorphic Features. J. Med. Genet. 2018, 55, 408-414. [CrossRef]

281. Miralles Fusté, J.; Shi, Y.; Wanrooij, S.; Zhu, X.; Jemt, E.; Persson, Ö.; Sabouri, N.; Gustafsson, C.M.; Falkenberg, M. In Vivo Occupancy of Mitochondrial Single-Stranded DNA Binding Protein Supports the Strand Displacement Mode of DNA Replication. PLoS Genet. 2014, 10, e1004832. [CrossRef] [PubMed]

282. Courage, C.; Jackson, C.B.; Hahn, D.; Euro, L.; Nuoffer, J.-M.; Gallati, S.; Schaller, A. SDHA Mutation with Dominant Transmission Results in Complex II Deficiency with Ocular, Cardiac, and Neurologic Involvement. Am. J. Med. Genet. A 2017, 173, 225-230. [CrossRef] [PubMed]

283. Zehavi, Y.; Saada, A.; Jabaly-Habib, H.; Dessau, M.; Shaag, A.; Elpeleg, O.; Spiegel, R. A Novel de Novo Heterozygous Pathogenic Variant in the SDHA Gene Results in Childhood Onset Bilateral Optic Atrophy and Cognitive Impairment. Metab. Brain Dis 2021. [CrossRef]

284. Metodiev, M.D.; Gerber, S.; Hubert, L.; Delahodde, A.; Chretien, D.; Gérard, X.; Amati-Bonneau, P.; Giacomotto, M.-C.; Boddaert, N.; Kaminska, A.; et al. Mutations in the Tricarboxylic Acid Cycle Enzyme, Aconitase 2, Cause Either Isolated or Syndromic Optic Neuropathy with Encephalopathy and Cerebellar Atrophy. J. Med. Genet. 2014, 51, 834-838. [CrossRef] [PubMed]

285. Neumann, M.A.-C.; Grossmann, D.; Schimpf-Linzenbold, S.; Dayan, D.; Stingl, K.; Ben-Menachem, R.; Pines, O.; Massart, F.; Delcambre, S.; Ghelfi, J.; et al. Haploinsufficiency Due to a Novel ACO2 Deletion Causes Mitochondrial Dysfunction in Fibroblasts from a Patient with Dominant Optic Nerve Atrophy. Sci Rep. 2020, 10, 16736. [CrossRef]

286. Sadat, R.; Barca, E.; Masand, R.; Donti, T.R.; Naini, A.; de Vivo, D.C.; di Mauro, S.; Hanchard, N.A.; Graham, B.H. Functional Cellular Analyses Reveal Energy Metabolism Defect and Mitochondrial DNA Depletion in a Case of Mitochondrial Aconitase Deficiency. Mol. Genet. Metab. 2016, 118, 28-34. [CrossRef] [PubMed]

287. Bosch, D.G.M.; Boonstra, F.N.; Gonzaga-Jauregui, C.; Xu, M.; de Ligt, J.; Jhangiani, S.; Wiszniewski, W.; Muzny, D.M.; Yntema, H.G.; Pfundt, R.; et al. NR2F1 Mutations Cause Optic Atrophy with Intellectual Disability. Am. J. Hum. Genet. 2014, 94, 303-309. [CrossRef]

288. Tang, K.; Xie, X.; Park, J.-I.; Jamrich, M.; Tsai, S.; Tsai, M.-J. COUP-TFs Regulate Eye Development by Controlling Factors Essential for Optic Vesicle Morphogenesis. Development 2010, 137, 725-734. [CrossRef]

289. Kao, C.-Y.; Xu, M.; Wang, L.; Lin, S.-C.; Lee, H.-J.; Duraine, L.; Bellen, H.J.; Goldstein, D.S.; Tsai, S.Y.; Tsai, M.-J. Elevated COUP-TFII Expression in Dopaminergic Neurons Accelerates the Progression of Parkinson's Disease through Mitochondrial Dysfunction. PLoS Genet. 2020, 16, e1008868. [CrossRef] [PubMed]

290. Shi, Y.; Inoue, H.; Wu, J.C.; Yamanaka, S. Induced Pluripotent Stem Cell Technology: A Decade of Progress. Nat. Rev. Drug Discov. 2017, 16, 115-130. [CrossRef]

291. Cowan, C.S.; Renner, M.; De Gennaro, M.; Gross-Scherf, B.; Goldblum, D.; Hou, Y.; Munz, M.; Rodrigues, T.M.; Krol, J.; Szikra, T.; et al. Cell Types of the Human Retina and Its Organoids at Single-Cell Resolution. Cell 2020, 182, 1623-1640.e34. [CrossRef]

292. Arroyo, J.D.; Jourdain, A.A.; Calvo, S.E.; Ballarano, C.A.; Doench, J.G.; Root, D.E.; Mootha, V.K. A Genome-Wide CRISPR Death Screen Identifies Genes Essential for Oxidative Phosphorylation. Cell Metab. 2016, 24, 875-885. [CrossRef]

293. Aleo, S.J.; Del Dotto, V.; Fogazza, M.; Maresca, A.; Lodi, T.; Goffrini, P.; Ghelli, A.; Rugolo, M.; Carelli, V.; Baruffini, E.; et al. Drug Repositioning as a Therapeutic Strategy for Neurodegenerations Associated with OPA1 Mutations. Hum. Mol. Genet. 2021, 29, 3631-3645. [CrossRef] [PubMed]

294. Doudna, J.A. The Promise and Challenge of Therapeutic Genome Editing. Nature 2020, 578, 229-236. [CrossRef] [PubMed]

295. Laha, B.; Stafford, B.K.; Huberman, A.D. Regenerating Optic Pathways from the Eye to the Brain. Science 2017, 356, 1031-1034. [CrossRef] [PubMed] 